\title{
PROCESSO DE ELABORAÇÃO NORMATIVA E POLÍTICAS PÚBLICAS: A VISÃO JURÍDICO-INSTITUCIONAL DA POLÍTICA DE FORMAÇÃO DE PROFESSORES DA EDUCAÇÃO BÁSICA ${ }^{1}$
}

\author{
NORMATIVE PROCESS AND PUBLIC POLICIES: A LEGAL- \\ INSTITUTIONAL VIEW OF THE BASIC EDUCATION TEACHER \\ TRAINING POLICY
}

IGHOR RAFAEL DE JORGE ${ }^{2}$

RESUMO: Este artigo pretende analisar a base normativa que disciplina a ação regulatória nos cursos de formação de professores da educação básica, a fim de identificar como os diversos suportes normativos (leis, pareceres, resoluções, etc.) influem sobre a definição da identidade formativa dos profissionais do magistério. Considerando que no desenho jurídico-institucional da política educacional brasileira há uma concentração de prerrogativas no Poder Executivo, será enfatizada a atividade normativa desempenhada pelo Conselho Nacional de Educação (CNE). Considera-se que o direito, visto como um "mapa de responsabilidades", pode contribuir para evitar sobreposições normativas, lacunas e disputas nas políticas públicas. A Legística, campo de estudos centrado na racionalização do processo de elaboração normativa, por meio de técnicas de redação e de avaliação de impacto, foi o marco teórico escolhido para a análise qualitativa da cadeia normativa, dada a relação com o ciclo de políticas públicas, em especial pela articulação entre meios (atos normativos) e fins (resultados esperados pelos formuladores), o que viabiliza o estabelecimento de um debate interdisciplinar genuíno entre o Direito e o campo de análise de políticas públicas. Ao final, demonstra-se empiricamente como a base normativa, caracterizada pela

\footnotetext{
${ }^{1} \mathrm{O}$ artigo é produto da dissertação de mestrado do autor, defendida na Faculdade de Direito da Universidade de São Paulo em abril de 2018 (JORGE, 2018b), sob a orientação da Professora Maria Paula Dallari Bucci. Agradeço aos pesquisadores do grupo Estado, Direito e Políticas Públicas (FD/USP), coordenado pela Professora Maria Paula Dallari Bucci, pelas sugestões e críticas feitas à versão anterior deste texto, bem como pelo diálogo e aprendizado sobre as linhas de trabalho da abordagem Direito e Políticas Públicas. Algumas das ideias apresentadas neste texto foram expostas, de forma preliminar e sintetizada, nos anais do IX Congresso da AbraSD, realizado na FD/USP em 2018 (JORGE, 2018a).

${ }^{2}$ Mestre em Direito do Estado pela Faculdade de Direito da USP. Pesquisador na área de Direito e Políticas Públicas. Contato: ighor@usp.br.
} 
dispersão temática, antinomias e excesso de leis simbólicas, é desprovida de consistência sistêmica. Para a superação desse problema, indica-se a adoção de procedimentos de consolidação das normas, a produção de "leis quadros", com a definição de eixos centrais da política de formação de professores e dos planos de carreira, e a utilização de técnicas de juridificação baseadas na indução de comportamentos.

Palavras-Chave: Direito e políticas públicas; Política educacional; Direito à educação; Formação de professores; Implementação de políticas públicas.

ABSTRACT: This article aims to analyze the normative framework that regulates the teacher training courses, in order to identify how the various normative supports (laws, resolutions, etc.) influence the definition of formative identity. Considering that in Brazilian legal-institutional design of educational public policy, there is a concentration of prerogatives in the Executive Branch, the normative activity performed by the National Education Council will be emphasized. It is considered that the law, seen as a "map of responsibilities", can collaborate to avoid overlaps, gaps or rivalries in public policies. Legistics, a field of study centered on the rationalization of the normative elaboration process through regulatory impact analysis, was the theoretical framework chosen for the qualitative analysis of the legislation, given its relationship with the policy cycle, especially by the articulation between means (normative acts) and ends (results expected by policymakers), which enables the establishment of a genuine interdisciplinary debate between Law and the Policy Analysis field. In the end, it is empirically demonstrated how the normative basis, characterized by thematic dispersion, antinomies and excess of symbolic laws, is devoid of systemic consistency. To overcome this problem, the adoption of procedures for the consolidation of norms, the production of "framework laws", with the definition of main points of teacher training policy and career plans, and the use of soft law, are suggested.

KEYWORDS: Law and Public Policy; Educational policy; Right to education; Teacher training; Policy implementation.

\section{INTRODUÇÃO}

O objetivo principal do presente artigo é analisar o quadro normativo relacionado à ação regulatória nos cursos de formação de professores da educação básica, a partir da abordagem Direito e Políticas Públicas (DPP) (BUCCI, 2013a, 2017, 2019; BUCCI; COUTINHO, 2017), a fim de identificar como os diversos 
suportes normativos (leis, pareceres, resoluções, etc.) podem contribuir para a definição da identidade formativa dos profissionais do magistério.

A abordagem DPP 3 , como observam Bucci e Coutinho (2017, p. 4), integra os juristas ao campo multidisciplinar de estudos das políticas públicas, uma vez que supera uma visão "meramente descritiva, estática e formal do elemento jurídico e, por isso, não isola ou disseca o direito do contexto político-institucional em que opera". Compreender o Direito como parte do arranjo institucional ${ }^{4}$ de políticas públicas "é supor que normas jurídicas estruturam seu funcionamento, regulam seus procedimentos e se encarregam de viabilizar a articulação entre atores direta e indiretamente ligados a tais políticas" (COUTINHO, 2015, p. 468).

Em linhas gerais, a perspectiva jurídico-institucional, na qual a abordagem DPP é calcada, enfatiza três elementos: (i) a organização do programa ou estratégia governamental; (ii) os papéis institucionais ("quem faz o quê") e (iii) a mobilização da máquina pública e a atuação dos grupos de interesse (BUCCI, 2015, p. 9).

Cabe ressaltar que as políticas públicas não se confundem com as disposições jurídicas com as quais se relacionam, porém, são estruturadas, por força do princípio da legalidade administrativa, sobre uma base legal (BUCCI, 2013a, p. 248). O arcabouço jurídico, mais do que cristalizar as opções políticas, funciona como um "mapa de divisão de responsabilidades e tarefas nas políticas públicas" (COUTINHO, 2015, p. 468). É a base normativa, composta por leis, decretos, portarias ou outros atos normativos (BUCCI, 2002, p. 257), que, ao menos idealmente, determina o núcleo de sentido e confere tratamento sistemático ${ }^{5}$ à ação governamental (BUCCI, 2015, p. 9).

Assim, serão enfatizados os elementos principais do arranjo jurídicoinstitucional da política brasileira de formação de professores da educação básica. Para tanto, serão aplicados os fundamentos teóricos e as aplicações práticas da

\footnotetext{
${ }^{3}$ Ver neste dossiê o artigo de Maria Paula Dallari Bucci (2019a). Para Bucci (2017, p. 39), “a visão jurídico-institucional propiciada pela [abordagem DPP] confere especial relevo à identificação de como atuam os incumbidos dos vários papéis e de que maneira, também sob a perspectiva das instituições, se pode pensar na remodelação das formas de agir".

${ }^{4}$ A locução arranjo institucional designa o "conjunto de regras, mecanismos e processos que definem a forma particular como se coordenam atores e interesses na implementação de uma política pública específica. São os arranjos que dotam o Estado de capacidade de execução de seus objetivos. Ou, em outras palavras, são os arranjos que determinam a capacidade do Estado de implementar políticas públicas" (GOMIDE; PIRES, 2014, p. 19). Como expõe Bucci (2019b, p. 373), a dimensão jurídica do desenho institucional das políticas públicas, "as soluções jurídicas adotadas para um problema", são definidas a partir do processo de elaboração normativa, no âmbito dos Poderes Legislativo e Executivo, o que torna a Legística um campo de análise convergente.

${ }^{5}$ Como apontado por Flückiger (1999, p. 125), por um lado, a lei não é um ato isolado, coerente em si, é apenas uma etapa e um meio para a realização de políticas públicas, de forma que não pode ser dissociada do núcleo de sentido da estratégia governamental, por outro lado, a lei continua sendo a principal fonte de legitimidade das políticas públicas.
} 
Legística, campo da área de estudos legislativos, voltada para a racionalização e concepção estratégica das leis (FLÜCKIGER, 2019, p. 33), que tem como linhas de investigação não só o aperfeiçoamento da redação dos atos normativos, como também a preparação e "gestão das normas" para a adequada aplicação e cumprimento dos objetivos que orientaram a concepção (MORAIS, 2007, p. 210) ${ }^{6}$.

Embora diversos trabalhos no campo educacional tenham discutido a formação de professores sob o seu aspecto pedagógico, faltam abordagens jurídicas da questão. Como apontado na literatura de políticas educacionais e da economia da educação, dentre os diversos elementos que concorrem para a efetividade do direito à educação, a qualidade da formação de professores é um fator relevante ou o mais importante (BRUNS; LUQUE, 2015; COSTIN, 2017; GATTI et al., 2019; LOUZANO et al., 2010; LOUZANO; MORICONI, 2015; OCDE, 2011; SIMIELLI, 2015), em especial pelo impacto sobre o desempenho dos alunos.

A escolha da política pública de formação de professores como objeto de estudo jurídico também se justifica por ser uma das formas de concretização do princípio da valorização dos profissionais da educação escolar (CF/88, art. 206, inciso V) e por se tratar de ponto crucial para a efetiva estruturação de um regime de colaboração federativa em matéria educacional (CF/88, art. 211), sobretudo em virtude de sua implementação descentralizada e desarticulada (BACHUR, 2016, p. 381), contando com a atuação da União, Estados e Municípios e mobilização de diversas estruturas governamentais, como o MEC, CNE, CAPES e os Conselhos de educação dos Estados.

A formação de professores nas instituições de ensino superior é mais subordinada à regulamentação federal, porém, os modelos formativos têm maior impacto nos estados e municípios, que recebem os professores em suas redes (ABRUCIO, 2016, p. 36). Portanto, a política de formação docente pode ser um ponto de partida para a construção de um efetivo regime de colaboração em matéria educacional: é "na formação de professores que os sistemas municipais, estaduais e federal de ensino podem ser articulados" (BACHUR, 2016, p. 381).

Segundo Gatti (2013), a política de formação de professores deve ter como alvo a profissionalização da carreira do magistério, o que depende da delimitação dos conhecimentos e das formas de ação dos docentes: "com essas concepções, colocase a formação de professores para além do improviso, na direção de superação de uma posição missionária ou de ofício, deixando de lado ambiguidades quanto ao seu papel como profissional" (GATTI, 2013), ou seja, a docência não pode ser compreendida como "ação espontânea", devendo ser fundada no domínio de conhecimentos científicos e humanistas (GATTI et al., 2019, p. 19).

Gatti (2013) esclarece que a profissionalidade docente deve ser vista como "o conjunto de características de uma profissão que enfeixam a racionalização dos conhecimentos e das habilidades necessários ao exercício profissional" e a

${ }^{6}$ Neste trabalho, as expressões "lei" e "normas" serão tomadas, sem maior rigor técnico, como sinônimas. 
profissionalização dos docentes "como a obtenção de um espaço autônomo" próprio ao exercício de sua profissionalidade, "com valor claramente atribuído pela sociedade como um todo".

Com efeito, o principal propósito desta pesquisa é identificar como a base normativa que orienta as estruturas curriculares dos cursos de licenciatura influencia a delimitação da profissionalidade da carreira docente e a valorização do ambiente de profissionalização. A título secundário, verificar até que ponto a política de formação de professores da educação básica está alinhada à concepção constitucional de educação.

Como apontam Gatti e outros educadores (2019), a formação de professores é um problema social, não só pela relevância da carreira docente e "do trato incerto que tem merecido mediante políticas descontinuadas e pela pouca discussão social relativa a seu valor social concreto na contemporaneidade", como também pela definição dos fundamentos dessa formação e das práticas a ela associadas ${ }^{7}$. Assim, o alcance dos objetivos constitucionais ainda é um desafio, o que depende do êxito das políticas públicas voltadas para a valorização da carreira docente.

$\mathrm{O}$ presente trabalho subdivide-se em três partes. Inicialmente, será demonstrada a convergência entre a abordagem DPP e a Legística e a utilidade dessa abordagem para a análise do problema de pesquisa. Em seguida, será feita a avaliação do quadro normativo, com ênfase na produção do Conselho Nacional de Educação (CNE), que nos termos do art. $7^{\circ}$ da Lei n. 9.131, de 1995, possui funções normativas e deliberativas no campo educacional. Por fim, serão propostos alguns encaminhamentos.

Como será verificado, o quadro normativo que disciplina a formação de professores é demasiadamente simbólico e com poucos direcionamentos para a implementação das diretrizes curriculares pelas instituições de ensino. Os diversos subsistemas de normas que regulam a carreira do magistério não se articulam adequadamente, sobretudo por conta de arranjos jurídico-institucionais fragmentários, que são entraves para a delimitação da identidade profissional das professoras e professores.

Cumpre observar que, por se tratar de trabalho de natureza empírica, com ênfase na produção normativa do CNE, não faz parte do seu propósito descrever a proteção específica do Direito à Educação na Constituição Federal de 1988, uma vez que o exame do conteúdo das diretrizes e princípios constitucionais, muitos

\footnotetext{
7 "O trabalho dos professores é o ensino voltado à aprendizagem, dirigido intencionalmente à promoção de mudanças qualitativas no desenvolvimento mental do aluno. O professor realiza plenamente seu trabalho quando ajuda o aluno a adquirir capacidades para novas operações mentais e a operar mudanças qualitativas em sua personalidade. Para isso, um currículo de formação profissional de professores deve ter como eixo e como referências para todas as disciplinas do currículo os elementos clássicos constitutivos da didática: o que ensinar?, para quem ensinar?, como ensinar?, em que condições ensinar?" (LIBÂNEO, 2011).

${ }^{8}$ Artigos 205 a 214 da CF de 1988. Para uma análise completa, ver Ranieri (2009) e Ximenes (2014).
} 
deles expressamente aplicáveis à carreira do magistério ${ }^{9}$, exigiria uma análise mais extensa do que a possível neste artigo. Entretanto, é necessário observar que as ações governamentais no campo educacional devem não só promover a qualificação para o trabalho, como também o pleno desenvolvimento da pessoa e seu preparo para a cidadania, de acordo com uma concepção abrangente e ambiciosa de educação, na forma prevista no artigo 205.

\section{Direito, Legística E Políticas PúblicAs: A Lei COMO INSTRUMENTO DE GOVERNO ${ }^{10}$}

Como expõe Maria Paula Dallari Bucci (2013, p. 107), a área jurídica é a "última participante" do debate no campo de análise de políticas públicas, intenso na Ciência Política desde a década de $1930^{11}$. A maior parte das formulações jurídicas nacionais nesse campo, desenvolvidas, em especial, a partir dos anos 2000, privilegia a temática da judicialização dos direitos sociais.

Os enfoques tradicionais sobre a judicialização, centrados nos papéis institucionais do Poder Judiciário, contribuíram para avanços consideráveis na conceituação e concretização dos Direitos Econômicos, Sociais e Culturais (DESC), porém, essas perspectivas não exploram a dimensão jurídica presente nos elementos e etapas do ciclo das políticas públicas (DUARTE, 2015, p. 13), descrita por Coutinho (2015, p. 452) como o "papel coordenador e articulador desempenhado pelo direito público e pelos juristas na modelagem institucional necessária à implementação de políticas".

Geralmente, os processos de formação das normas, a "política legislativa", são pouco explorados na pesquisa jurídica, fato que decorre de uma "espécie de hipertrofia tecnicista da dogmática" que separou os momentos de elaboração e aplicação da norma, de modo que "ao jurista caberia aceitar o ato normativo como elemento dado, posto, apto a ser, apenas a partir de então, avaliado, criticado e interpretado" (PAULA, 2016, p. 27).

A percepção de que a eficiência da legislação e das políticas públicas depende da adoção de técnicas voltadas para a qualidade dos atos normativos também motivou, em meados da década de 1990, a difusão de diretrizes e recomendações pela Organização para Cooperação e Desenvolvimento Econômico (OCDE), por meio de relatórios e encontros (BAR-SIMAN-TOV, 2019, p. 285, MORAIS, 2007, p. 53, PAULA, 2016, p. 330), fato que influenciou a produção acadêmica relativa à

\footnotetext{
${ }^{9}$ Art. 206, incisos II, III, V, VI, VIII e Art. 60 da ADCT.

10 A noção de norma como instrumento de governo ("rule as tools of government") foi extraída de Baldwin (1995).

${ }^{11}$ Conforme Marques e Souza (2016, p. 321), a consolidação das políticas públicas como campo de estudos da ciência política no Brasil é recente, tendo, contudo, registrado substancial avanço e disseminação desde o fim dos anos de 1990, "por um lado dialogando crescentemente com a literatura internacional sobre o tema, e por outro contribuindo de forma teórica para uma melhor compreensão do Estado e do sistema político brasileiro".
} 
Legística ou Ciência da Legislação e a adoção de políticas legislativas ${ }^{12}$, com enfoque não só na qualidade formal como também substancial dos atos normativos (MORAIS, 2007, p. 209).

Note-se que o desenvolvimento da Legística enquanto campo de estudos, converge com o surgimento do Estado Social de Direito (MORAIS, 2007, p. 87; CLÈVE, 2011, p. 46) ${ }^{13}$. Na concepção liberal de Estado, atrelada à teoria clássica da separação dos poderes, a atividade normativa, adstrita ao Legislativo, era voltada para a contenção do poder. Entretanto, no Estado Social, com a ação do Estado direcionada para a concretização de finalidades materiais ${ }^{14}$, o Poder Executivo passou a desempenhar um papel proeminente. Como consequência, ocorreu um alargamento do princípio da legalidade administrativa, que passou a contemplar não só a lei em sentido formal (FLÜCKIGER, 2019, p. 257), mas também todo um bloco de legalidade.

A Legística pode ser decomposta em duas linhas investigativas, denominadas Legística Formal e Legística Material. Em linhas gerais, a Legística Formal é voltada para os aspectos de comunicação legislativa, com ênfase na adoção de técnicas de redação, sistematização e consolidação dos atos normativos, direcionadas para a clareza, precisão e correção gramatical das normas (MORAIS, 2007, p. 211). Já a Legística Material é a dimensão centrada no aprimoramento substancial das normas, por meio de técnicas de avaliação de impacto normativo, dirigida ao cumprimento dos objetivos que orientaram a aprovação da lei (MORAIS, 2007, p. 211).

Na abordagem DPP, o direito é concebido como "caixa de ferramentas" para a modelagem de programas e estratégias governamentais (COUTINHO, 2015, p. 469). São de grande relevância as normas infralegais, estratégicas para disciplinar a operacionalização dos programas, uma vez que facilitam a inserção de ajustes necessários às necessidades identificadas durante a implementação dos programas governamentais:

\footnotetext{
12 Podem ser mencionadas como exemplos de políticas legislativas brasileiras a Lei Complementar $\mathrm{n}^{\circ}$ 95, de 26 de fevereiro de 1998, que dispõe sobre a elaboração, a redação, a alteração e a consolidação das leis e estabelece normas para a consolidação dos atos normativos, e o Decreto ${ }^{\circ}$ 9.191/2017, que contém prescrições formais e materiais, além de um modelo de check list prévio à elaboração da norma.

${ }^{13}$ Para uma exposição detalhada do desenvolvimento histórico e fundamentos da Legística, ver BarSiman-Tov (2019), Delley (2004), Flückiger (1999, 2019) e Morais (2007).

14 "O desenvolvimento contemporâneo da Legística acompanha o do Estado intervencionista, o Estado das grandes políticas públicas, que ambiciona, se não revolucionar a sociedade, pelo menos influenciar o seu curso, quer seja em matéria econômica (estimular o crescimento, domesticar a inflação), social (combater as desigualdades, evitar a exclusão) ou em matéria de formação (promover uma parte determinada de uma faixa de idade a um grau explícito de formação) principalmente" (FLÜCKIGER; DELLEY, 2007, p. 37).
} 
[A]lente analítica de Direito e Políticas Públicas dá mais atenção para as normas infralegais, como os decretos, as portarias e os regulamentos, em razão do seu papel no preenchimento dos procedimentos e rotinas que definem, na ponta do processo, o funcionamento último das disposições mais abstratas dos comandos constitucionais e legais. Tais normas, longe de serem de relevância menor se comparadas às grandes diretrizes e comandos programáticos, são, elas próprias, a substância de que são feitas, quotidianamente, as políticas públicas [...] a aplicação satisfatória da base normativa (o que não é, como dito, um aspecto menor, dado o problema crônico de inefetividade das normas no Brasil) depende diretamente de como as normas são construídas, combinadas, revistas e ajustadas no curso do processo constitutivo das políticas públicas que é sua fase de implementação. Aqui pesa o aspecto processual isto é, a participação nas decisões que concretizam o texto normativo, mas também o aspecto formal. Também é relevante a simplicidade e a clareza das categorias normativas, de modo que a interpretação esteja ao alcance dos destinatários leigos - e, de modo geral, de todos os envolvidos no arranjo jurídico-institucional -, dependendo menos de disputas de sentido entre os aplicadores "especializados" ou "técnicos" (integrantes de órgãos de controle, procuradorias, Ministério Público e juízes, por exemplo) (BUCCI; COUTINHO, 2017).

A problematização da decisão de legislar pode ser decomposta, de forma esquemática, em sete fases (DELLEY, 2004, p. 102): (i) definição do problema; (ii) determinação de objetivos; (iii) estabelecimento de cenários alternativos; (iv) escolha das soluções; (v) avaliação prospectiva; (vi) execução e (vii) avaliação retrospectiva. Como aponta Flückiger (2019, p. 33), as fases da Legística Material estão imbricadas com o ciclo de políticas públicas ${ }^{15}$.

Para Flückiger (2019, p. 621) e Paula (2016, p. 59), as avaliações de impacto legislativo integram e até mesmo se confundem com os métodos de avaliação de políticas públicas, na medida em que qualquer política pública deve, em última análise, basear-se em um arcabouço legal, que necessita ser estrategicamente concebido para atingir uma finalidade socialmente relevante. Não basta a mera validação formal.

\footnotetext{
${ }^{15} \mathrm{O}$ "ciclo de políticas públicas" é um dos modelos explicativos mais adotados para o estudo de politicas públicas. De acordo com Howlett, Ramesh e Perl (2013, p. 15), o ciclo abrange cinco fases: (i) montagem da agenda, correspondente ao reconhecimento do problema; (ii) formulação da política, que designa a etapa de estabelecimento de propostas de solução; (iii) tomada da decisão política, consistente na escolha da solução; (iv) implementação da política, materializada na efetivação da solução e (v) avaliação da política, por meio do monitoramento dos resultados.
} 
A Legística Material valoriza a análise do impulso legiferente, a decisão de legislar, (DELLEY, 2004). Como veremos, além da investigação no âmbito legislativo, doutrinário e jurisprudencial, deve ser feita pesquisa interdisciplinar, que contemple a análise do impacto econômico, social e político do ato normativo (DELLEY, 2004, p. 109; MENDES, 2007, p. 2), o que abre caminho para uma abordagem multidisciplinar.

\section{Definição do problema}

Para Flückiger (2019, p. 36), a Legística Material, quando materializada na análise de impacto prospectiva ou ex ante, pode ser estruturada, de forma esquemática, em três fases: fase analítica, consistente no exame do impulso legiferante, levantamento dos dados e dimensionamento da relevância do problema; fase teleológica, que abrange a avaliação e determinação dos objetivos relevantes; fase estratégica, consistente na avaliação dos meios disponíveis, consideração dos impactos sociais, ambientais e econômicos e na determinação da melhor opção legislativa.

Partindo da consideração do problema, uma das dificuldades que envolve a efetivação do direito fundamental à educação, na dimensão normativa, no que concerne à carreira docente, é a definição do conteúdo jurídico da formação de professores. Faltam nas normas padrões claros "de como deve ser formado o professor" e "quais habilidades devem ter os profissionais do magistério", conceitos que são disputados por grupos com diferentes interesses e concepções pedagógicas sobre as políticas educacionais, o que torna o processo de elaboração normativa conflituoso e moroso.

Conforme estudo financiado pelo Banco Mundial (BRUNS; LUQUE, 2012, p. 152), as políticas educacionais dos países da América Latina, em especial do Brasil, privilegiam o aumento dos anos de estudo dos educadores (qualificação formal), em detrimento de alterações curriculares.

Na década de 1980 a avaliação da qualidade dos professores era mensurada apenas por dois indicadores: escolaridade e certificação. As pesquisas internacionais mais recentes, porém, têm se voltado para a compreensão das competências e habilidades necessárias para o aprendizado dos alunos, desenvolvidas na formação inicial e continuada dos profissionais do magistério (ABRUCIO, 2016, p. 9).

O modelo da política de formação de professores pode ser explicado a partir da noção de dependência da trajetória (path dependence), conceito do neoinstitucionalismo histórico, corrente da ciência política, que parte da premissa de que as preferências dos atores sociais, políticos e econômicos são moldadas por organizações coletivas e instituições que carregam traços da própria historia (IMMERGUT, 2007, p. 173), ou seja, os arranjos institucionais anteriores influenciam a estruturação das políticas públicas subsequentes (MARQUES, 2015, 
p. 663). Para Pierson (2000, p. 252), as etapas anteriores de uma determinada ação induzem a adoção de práticas em uma mesma direção, o que aumenta os custos de eventuais mudanças e condiciona a maneira pela qual novos desdobramentos ocorrerão, fatos denominados pelo autor como processos "autorreforçados" ou "retornos crescentes".

No começo do século XX, as Escolas Normais de nível médio eram o espaço de formação de professores para as séries iniciais, ao passo que a formação dos professores para o curso secundário cabia às instituições de nível superior, nos cursos de licenciatura (GATTI; BARRETO, 2009, p. 38).

O curso de Pedagogia, regulamentado em 1939, era destinado à formação de bacharéis especialistas em educação e, secundariamente, à formação de docentes para as escolas normais (GATTI; BARRETO, 2009, p. 37), ou seja, tinha como enfoque a formação de "pensadores da educação" e gestores escolares. Entretanto, a partir da reforma universitária de 1968, a formação para o magistério nas séries iniciais foi deslocada para os cursos de pedagogia (GATTI; BARRETO, 2009, p. 40), o que desencadeou o esvaziamento gradativo dos cursos normais, mais próximos da dinâmica e das práticas das escolas, como espaço de formação de professores.

Libâneo (2013, p. 27) aponta que a formação de professores para a educação básica abrange duas dimensões. A primeira delas, teórico-científica, é centrada nas disciplinas em que o docente vai especializar-se e na formação pedagógica, que contempla "os conhecimentos de Filosofia, Sociologia, História da Educação e da própria Pedagogia que contribuem para o esclarecimento do fenômeno educativo no contexto histórico-social". A segunda dimensão, que o autor denomina como "técnico-prática", é direcionada à preparação profissional para o exercício da docência e é composta por disciplinas relacionadas à didática, bem como às metodologias específicas das matérias das áreas de Psicologia da Educação e Pesquisa Educacional.

No caso das licenciaturas para as disciplinas específicas, ainda prevalece o esquema denominado "3+1", estruturado na década de 1930 (GATTI et al., 2019, p. 23), consistente no acréscimo de apenas um ano à formação específica (bacharelado) para o exercício docente na educação básica, ou seja, é notória a separação entre os aspectos pedagógicos e práticos.

Cabe mencionar que na década de 1980 foram instituídos em alguns estados Centros Específicos de Formação e Aperfeiçoamento do Magistério (Cefams), de nível médio, voltados para a prática de ensino. Ainda que o modelo dos Cefams tenha sido considerado de grande qualidade formativa e tenha atraído bons candidatos para o exercício do magistério, em especial pela concessão de bolsas (ABRUCIO, 2015, p. 13), o fato é que foram extintos após a LDB de 199616, que

16 “Com formação em tempo integral, com três anos de curso, currículo voltado à formação geral e à pedagógica desses docentes, com ênfase nas práticas de ensino, os Cefams foram se expandindo em número e, pelas avaliações realizadas, conseguindo alto grau de qualidade na formação oferecida [...]Esses centros, que proviam a formação em nível médio, acabaram sendo 
fortaleceu o papel das licenciaturas e dos cursos de pedagogia, "apostando na suposição de que o aumento do grau de escolaridade traria automaticamente mais qualidade ao corpo docente da Educação Básica" (ABRUCIO, 2015, p. 13).

Algumas concepções pedagógicas enfatizam a formação prática do professor, porém, a formação universitária tradicional, como apontam alguns estudos, privilegia a formação teórica ${ }^{17}$. Como aponta Dourado (2009, p. 10), a dicotomia entre teoria e prática "tem resultado em legislações diversas no campo e, de maneira geral, pouco tem contribuído para o avanço do estado da arte da formação e para a atuação profissional do professor", uma vez que o cerne da questão é a combinação entre as duas dimensões ${ }^{18}$.

$\mathrm{Na}$ análise do conteúdo das ementas dos projetos pedagógicos de algumas instituições de ensino, Gatti (2010) constatou a predominância de disciplinas ligadas aos fundamentos teóricos da educação, em detrimento de questões profissionalizantes ("o que ensinar" e "como ensinar"):

há instituições que propõem o estudo dos conteúdos de ensino associados às metodologias, mas, ainda assim, de forma panorâmica e pouco aprofundada. Então, mesmo no conjunto de $28,9 \%$ de disciplinas que podem ser classificadas como voltadas à formação profissional específica, o que sugerem as ementas é que esta formação é feita de forma ainda muito insuficiente, pelo grande desequilíbrio entre teorias e práticas, em favor apenas das teorizações mais abstratas [...] Quando se agrega ao conjunto de disciplinas dedicadas aos fundamentos da educação as disciplinas variadas e gerais, que poderíamos chamar de "outros saberes", e as "atividades complementares", chega-se a quase $40 \%$ do conjunto de disciplinas oferecidas. Por outro lado, fica pouco claro o que nos currículos se qualifica como "atividades complementares". Estas não são especificadas. Juntando a esse panorama as disciplinas optativas ofertadas, a maioria com o caráter de formação genérica [...] pode-se inferir que a parte curricular que propicia o desenvolvimento de habilidades profissionais específicas para a atuação nas escolas e nas salas de aula fica bem reduzida.

fechados nos anos subsequentes à promulgação da Lei no 9.394/96, nova LDB, que transferiu a formação desses professores para o nível superior" (GATTI; BARRETO, 2009, p. 39).

17 "O modelo propugnado pelas universidades de ponta, mormente as públicas, se concentrou na área de pesquisa, de modo que vêm formando, em certa medida, mais "pensadores da Educação", em vez de docentes preparados para as escolas públicas reais da Educação Básica, seja em termos de metodologias de ensino, seja em termos vocacionais" (ABRUCIO, 2015, p. 14).

${ }^{18}$ Ver também Abrucio (2015), Gatti e Barreto (2009); Gatti et al. (2011); Gatti (2015); Gatti et al. (2019). 
Na avaliação de Dourado (2009, p. 46), as diretrizes curriculares e a carga horária dos cursos de formação de professores são disciplinadas de forma conflitante na legislação educacional, o que torna necessária maior convergência entre as diversas orientações normativas para os cursos de formação de professores.

Da mesma forma, os estágios pouco contribuíram para aproximação dos componentes práticos e teóricos, na maioria das vezes, são atividades burocráticas, sem projetos, destinadas ao cumprimento de créditos, baseadas no mero acompanhamento de aulas, "e não uma política sistemática de formação docente" (ABRUCIO, 2015, p. 45). Ou seja, também não favorecem a articulação entre as teorias e práticas educacionais.

Muitas das práticas históricas foram cristalizadas na legislação, em normas de hierarquia variada. O quadro normativo da política de formação de professores da educação básica a ser considerado inclui, além das disposições constitucionais, a Lei 9.394/96 (Lei de Diretrizes e Bases da Educação Nacional), a Lei 13.005/14 (Plano Nacional da Educação) e os atos normativos editados pelo Poder Executivo.

A LDB de 1996 possui um título dedicado aos profissionais da educação, porém, não foi delineada a identidade formativa- profissionalidade- dos docentes da educação básica, o que enfraquece a profissionalização da carreira do magistério. Em relação ao ambiente formativo, a redação da LDB é pouco clara e aparentemente ambígua. Foi estabelecida, como regra, a formação em nível superior, em cursos de licenciatura plena (art. 62), permitida, em caráter excepcional, a formação oferecida no ensino médio, na modalidade normal, para o exercício do magistério na educação infantil e nos anos iniciais do ensino fundamental.

Também foi prevista a figura dos Institutos Superiores de Educação (art. 63), que seriam, na concepção inicial, centros formativos voltados para a multidisciplinaridade, práticas de ensino e articulação entre as formações disciplinares e pedagógicas, um aparente contraponto ao modelo de formação universitário (ABRUCIO, 2015, p. 13), com cursos desintegrados, "licenciaturas isoladas entre si, ancoradas em departamentos disciplinares estanques" (GATTI et al., 2011, p. 96).

O objetivo foi o estabelecimento de um espaço próprio de formação de professores, inicial e continuada, que articulasse, por meio de concepção curricular integrada, os diversos cursos de formação docente ${ }^{19}$. Seriam ofertados, nos Institutos Superiores de Educação, os cursos normais superiores, destinados à

19 É imprescindível o estabelecimento de um núcleo interdisciplinar das licenciaturas nas instituições de ensino, para articulação entre os cursos e os aspectos didático-pedagógicos. $\mathrm{Na}$ análise de Gatti (2015, p. 239), "não há nas universidades uma unidade, um centro, uma faculdade que abrigue a formação de professores de modo integrado e em articulação com outros institutos ou faculdades [...]. As licenciaturas se 'dissolvem' entre várias unidades, mostram-se dispersas na instituição, não têm um instituído básico de referência, e não tem um lugar claro nas universidades, como lócus centralizado de pesquisa, ensino e extensão, com metas claras para o seu conjunto e seu papel formativo específico, com administração e financiamento próprios". 
formação de educadores para o ensino infantil e séries iniciais do ensino fundamental, e programas de educação continuada para os profissionais de educação de diversos níveis. Assim, provavelmente, os cursos de pedagogia seriam direcionados para a gestão escolar e áreas afins.

Entretanto, a previsão da LDB não teve efeito concreto, sobretudo pela falta de medidas estratégicas e normativas que induzissem a adoção da nova estrutura formativa. Como apontam Gatti e Barreto (2009), a oferta de cursos no âmbito do modelo institucional dos Institutos Superiores de Educação exigiria não só uma estrutura integrada, mas também condições específicas para a contratação de docentes, características que aumentariam os custos e demandariam a reestruturação organizacional das instituições de ensino, ou seja, mudanças de culturas formativas que foram de encontro às perspectivas dos grupos de interesse consolidados (academia, sindicatos, instituições de ensino, etc.).

No plano infralegal, compete ao CNE, órgão vinculado ao MEC, a definição substancial do conteúdo da formação inicial docente, haja vista que, simetricamente, cabe à União baixar normas gerais sobre cursos de graduação e pós-graduação (art. $9^{\circ}$, inciso VII da LDB/1996) e autorizar, reconhecer, credenciar, supervisionar e avaliar, respectivamente, os cursos das instituições de educação superior e os estabelecimentos do seu sistema de ensino (art. $9^{\circ}$, inciso IX da $\mathrm{LDB} / 1996)^{20}$.

O CNE, nos termos do art. $7^{\circ}$ da Lei n. 9.131, de 1995, que alterou dispositivos da Lei $\mathrm{n}^{\circ}$ 4.024, de 1961, possui funções normativas e deliberativas no campo educacional, aspecto reforçado pela LDB de 1996 (Lei n 9.394, de 1996), ao atribuir ao CNE "funções normativas e de supervisão e atividades permanentes" (art. $9^{\circ}$, $\S$ $\left.1^{\mathrm{o}}\right)^{21}$.

Compete ao CNE, ainda, resguardar a participação da sociedade no aprimoramento da Educação brasileira, bem como a prestação de assessoria ao Ministro de Estado da Educação no diagnóstico dos problemas educacionais e a deliberação sobre medidas para aperfeiçoar os sistemas de ensino, especialmente no que diz respeito à integração dos seus diferentes níveis e modalidades. Outra função reservada ao CNE, é a prestação de subsidio à elaboração e ao acompanhamento da execução do Plano Nacional de Educação (art. $7^{\circ}, \S 1^{1}$, ' $a^{\prime}$ ).

Entretanto, por mais que o CNE seja um órgão de caráter técnico, a escolha e nomeação dos conselheiros é feita pelo Presidente da República (art. $8^{\circ}, \S 1^{\circ}$ ).Diante disso, no contexto de um "presidencialismo de coalizão", combinação institucional

20 Ainda que os Conselhos de Educação dos Estados também sejam instituições relevantes na definição normativa de aspectos substantivos das políticas de formação de professores, o enfoque recairá sobre o CNE, uma vez que a regulação da educação no país está concentrada no âmbito do Governo Federal.

${ }^{21}$ A definição das funções do CNE ainda está prevista na antiga Lei de Diretrizes e Bases, revogada pela Lei no 9.394, de 1996, "com exceção dos artigos 6a a 9o". Um exemplo da falta de sistematicidade da legislação brasileira. 
do sistema de governo brasileiro, o papel normativo CNE acaba tendo reduzida função ordenadora, uma vez que os membros do conselho representam forças políticas nem sempre comprometidas inteiramente com a "direção governamental" ou representam grupos de interesse.

Na análise empírica de Bezerra (2017) sobre a forma de seleção dos membros do CNE, foi identificado que o processo de escolha é pouco transparente e, no que tange à trajetória profissional e acadêmica dos nomeados, há "subjetividade no critério de relevância à educação e à ciência” (BEZERRA, 2017, p. 133). A autora constatou que alguns conselheiros, do segmento privado com fins lucrativos, foram reiteradamente reconduzidos ao cargo (BEZERRA, 2017, p. 120).

Cabe ressaltar que as atividades deliberativas do Conselho Pleno, composto pela reunião da Câmara de Educação Básica e Câmara de Educação Superior, são exercidas mediante a edição de Indicações, Pareceres e Resoluções, aplicáveis a todos os sistemas de ensino quando homologadas pelo Ministério da Educação, que pode devolver o ato normativo para reexame (BUCCI; VILARINO, 2013, p. 142).

Conforme previsto no art. 18 do Regimento Interno do CNE, instituído pela Portaria MEC n. 1.306, de 2 de setembro de 1999, a Indicação é o ato proposto por um ou mais conselheiros, contendo sugestão justificada de estudo sobre qualquer matéria de interesse do CNE. Já o Parecer é o ato pelo qual o Conselho Pleno ou qualquer das Câmaras pronuncia-se sobre matéria de sua competência e a Resolução é o ato decorrente de parecer, destinado a estabelecer normas a serem observadas pelos sistemas de ensino sobre matéria de competência do Conselho Pleno ou das Câmaras. Assim, enquanto as resoluções devem ser as normas "propriamente ditas", os pareceres devem fornecer orientações "doutrinárias", sobre os fundamentos e formas de aplicação das resoluções.

\section{AVAliação do QUADro NORMATIVO DA POlíticA BRASILEIRA DE FORMAÇÃO DE PROFESSORES DA EDUCAÇÃO BÁSICA À LUZ DA LEGÍSTICA}

Neste tópico pretendemos, por meio das premissas e técnicas de Legística, avaliar o desempenho efetivo do quadro normativo que conforma a formação de professores. Para este fim, foram consideradas as Resoluções, decorrentes de Pareceres homologados pelo CNE no período de 1997 a 2017.

A partir da identificação do núcleo de sentido, o nexo de unidade da ação governamental, e da forma de combinação dos diversos atos normativos, será verificado se a legislação contribui para a formação de "um regime de efeitos jurídicos, combinados, articulados ou conjugados" (BUCCI, 2013a, p. 258). É essa "amarração jurídica" que justifica a política pública como objeto de interesse para o direito (BUCCI, 2013a, p. 257).

Serão enfatizadas, na análise qualitativa, as Diretrizes Curriculares Nacionais para o curso de graduação em pedagogia, licenciatura (Resolução $\mathrm{CNE} / \mathrm{CP} \mathrm{n}^{\circ}$ 1/2006) e as Diretrizes Curriculares Nacionais para a formação inicial em nível 
superior e para a formação continuada (Resolução CNE n²/2015), bases para toda a atuação regulatória nos cursos de formação de professores da educação básica.

Será adotado o modelo de análise normativa delineado por Atienza (2019), centrado na racionalidade do processo legislativo, combinado com a Avaliação Sucessiva de Impacto, consistente no instrumento metodológico da Legística Material "que tem como escopo analisar a repercussão dos efeitos reais produzidos por normas jurídicas que tenham entrado em vigor, tendo em vista a aferição de sua qualidade e eficiência" (MORAIS, 2007, p. 464).

No modelo de Atienza (2019, p. 176), sintetizado na tabela abaixo, o processo de produção das leis pode ser entendido como uma série de interações entre vários elementos: (1) os produtores da norma; (2) os destinatários da norma; (3) o "sistema legal" como um todo, ao qual novas leis são adicionadas; (4) os "fins" ou objetivos - no sentido mais amplo - que podem ser perseguidos pela legislação; e os (5) "valores" subjacentes a tais fins.

Atienza (2019, p. 176) também propõe uma noção multidimensional de racionalidade legislativa, decomposta em cinco níveis: linguística ou comunicativa (R1); sistemática ou legal-formal (R2); pragmática ou social (R3); teleológica ou instrumental (R4) e axiológica ou ético-moral (R5).

Tabela 1- Racionalidade legislativa e elementos do processo de elaboração normativa

\begin{tabular}{|c|c|c|c|c|c|}
\hline TIPO & EMISSOR & RECEPTORES & SISTEMA LEGAL & $\begin{array}{l}\text { FINS/ } \\
\text { OBJETIVOS }\end{array}$ & $\begin{array}{l}\text { VALORES } \\
\text { SUBJACENTES } \\
\text { AOS FINS }\end{array}$ \\
\hline $\begin{array}{l}\text { Linguística ou } \\
\text { Comunicativa } \\
\text { (R1) }\end{array}$ & Transmissor & $\begin{array}{l}\text { Destinatários } \\
\text { da mensagem } \\
\text { legal }\end{array}$ & $\begin{array}{l}\text { Conjunto de } \\
\text { declarações } \\
\text { (mensagens) e } \\
\text { canais para } \\
\text { transmiti-los }\end{array}$ & $\begin{array}{l}\text { Clareza, } \\
\text { precisão } \\
\text { linguística }\end{array}$ & Comunicação \\
\hline $\begin{array}{l}\text { Sistemática ou } \\
\text { legal-formal } \\
\text { (R2) } \\
\text { (quadro } \\
\text { normativo) }\end{array}$ & $\begin{array}{l}\text { Órgão } \\
\text { dotado do } \\
\text { poder de } \\
\text { produzir a } \\
\text { norma }\end{array}$ & $\begin{array}{l}\text { Indivíduos e } \\
\text { órgãos aos } \\
\text { quais as leis } \\
\text { são dirigidas }\end{array}$ & $\begin{array}{l}\text { Conjunto de } \\
\text { normas (em um } \\
\text { sentido amplo) } \\
\text { sistematicamente } \\
\text { estabelecido: } \\
\text { qualquer norma } \\
\text { deve se encaixar } \\
\text { na ordem legal } \\
\text { preexistente, ou } \\
\text { seja, deve ser } \\
\text { coerente } \\
\text { logicamente } \\
\text { consistente }\end{array}$ & $\begin{array}{l}\text { Sistematização } \\
\text { jurídica } \\
\text { (plenitude e } \\
\text { coerência). } \\
\text { Eliminação de } \\
\text { antinomias }\end{array}$ & $\begin{array}{l}\text { Segurança e } \\
\text { previsibilidade }\end{array}$ \\
\hline
\end{tabular}




\begin{tabular}{|c|c|c|c|c|c|}
\hline $\begin{array}{l}\text { Pragmática ou } \\
\text { social (R3) }\end{array}$ & $\begin{array}{l}\text { Órgão ao } \\
\text { qual a } \\
\text { obediência é } \\
\text { devida (ato } \\
\text { de } \\
\text { soberania) }\end{array}$ & $\begin{array}{l}\text { Burocracia; } \\
\text { indivíduos } \\
\text { que devem } \\
\text { obediência } \\
\text { (alvo da } \\
\text { norma) }\end{array}$ & $\begin{array}{l}\text { Conjunto de } \\
\text { regras efetivas } \\
\text { (ou de } \\
\text { comportamentos } \\
\text { observáveis) }\end{array}$ & $\begin{array}{l}\text { Cumprimento } \\
\text { da lei: tradução } \\
\text { de normas em } \\
\text { ações e no } \\
\text { impacto } \\
\text { comportamenta } \\
1 \text { desejado e/ou } \\
\text { implementação } \\
\text { da ação (Ver } \\
\text { Oliver- Lalana, } \\
\text { 2013) }\end{array}$ & $\begin{array}{l}\text { Manutenção da } \\
\text { ordem/ } \\
\text { Mobilização/ } \\
\text { Implementação } \\
\text { da política }\end{array}$ \\
\hline $\begin{array}{l}\text { Teleológica ou } \\
\text { instrumental } \\
(\mathrm{R} 4)\end{array}$ & $\begin{array}{l}\text { Portadores de } \\
\text { interesses } \\
\text { sociais } \\
\text { (indivíduos, } \\
\text { grupos de } \\
\text { pressão, etc.) }\end{array}$ & $\begin{array}{l}\text { Pessoas } \\
\text { afetadas pelo } \\
\text { regulamento } \\
\text { sobre } \\
\text { interesses ou } \\
\text { necessidades } \\
\text { sociais }\end{array}$ & $\begin{array}{l}\text { Conjunto de } \\
\text { meios para } \\
\text { atingir fins } \\
\text { sociais (com a } \\
\text { seleção de meios } \\
\text { sendo } \\
\text { informados pela } \\
\text { psicologia, } \\
\text { sociologia, } \\
\text { economia, etc.). A } \\
\text { norma é } \\
\text { instrumento para } \\
\text { o atingimento } \\
\text { dos objetivos da } \\
\text { estratégia } \\
\text { governamental }\end{array}$ & $\begin{array}{l}\text { Realização de } \\
\text { de objetivos } \\
\text { sociais: } \\
\text { redistribuição } \\
\text { da riqueza, } \\
\text { aumento ou } \\
\text { diminuição das } \\
\text { proteções } \\
\text { sociais, redução } \\
\text { do } \\
\text { desemprego, } \\
\text { manutenção de } \\
\text { vantagens, etc. }\end{array}$ & $\begin{array}{l}\text { Eficácia social } \\
\text { ou eficiência. } \\
\text { /Oliver-Lalana } \\
\text { (2013): } \\
\text { Impactos } \\
\text { econômicos e } \\
\text { não } \\
\text { econômicos. } \\
\text { Avaliação de } \\
\text { Impacto } \\
\text { Regulatório/ } \\
\text { Díez-Ripollés } \\
\text { (2019): } \\
\text { Participação/ } \\
\text { deliberação. }\end{array}$ \\
\hline $\begin{array}{l}\text { Axiológica ou } \\
\text { ético-moral } \\
\text { (R5) }\end{array}$ & $\begin{array}{l}\text { Autoridade } \\
\text { legítima }\end{array}$ & $\begin{array}{l}\text { Pessoas } \\
\text { moralmente } \\
\text { obrigadas a } \\
\text { obedecer à lei }\end{array}$ & $\begin{array}{l}\text { Conjunto de } \\
\text { normas, ações e } \\
\text { instituições } \\
\text { eticamente } \\
\text { avaliáveis }\end{array}$ & $\begin{array}{l}\text { Liberdade, } \\
\text { igualdade } \\
\text { justiça }\end{array}$ & $\begin{array}{l}\text { Dignidade } \\
\text { humana, } \\
\text { consenso, etc. }\end{array}$ \\
\hline
\end{tabular}

Fonte: extraído e adaptado de Atienza (2019).

A "racionalidade" normativa deve ser compreendida como um atributo complexo, que abrange várias dimensões e deve ser avaliada de acordo com diferentes critérios (formais, processuais e substantivos): "a racionalidade legislativa representa sempre um conjunto ideal de características linguísticas, sistemáticas, instrumentais e axiológicas" (OLIVER-LALANA, 2013, p. 140).

Com efeito, a racionalização do processo de elaboração das leis, propugnada pela Legística, não visa a "esterilização" da dinâmica política ou a simplificação dos conflitos sociais subjacentes, mas sim a produção de um quadro normativo que favoreça a implementação dos programas e estratégias governamentais, em consonância com os valores previstos na Constituição: 
A Legística tende a ir além da clássica metodologia jurídica, voltada para a aplicação da lei, pois não se limita à interpretação das regras existentes. Examina de um ponto de vista potencialmente crítico a própria lei, de maneira construtiva, uma vez que propõe um método de análise e de concepção. Não tem a pretensão de substituir a política, sendo um auxiliar na escolha-pela política- das soluções mais adequadas. Não exclui o uso de outros meios além da lei para resolver o problema da sociedade, pelo contrário, é uma forma de fornecer uma resposta com base na lei, e não necessariamente apenas por meio da lei (FLÜCKIGER, 2019, p. 34, tradução nossa).

Sieckmann (2013, p. 108) observa que a legislação em um estado constitucional democrático consiste, em grande medida, e em particular no que diz respeito aos direitos fundamentais, na "implementação do direito constitucional", um processo criativo ou construtivo de estabelecer normas baseadas no equilíbrio de princípios constitucionais.

Na visão de Barcellos (2017, p. 74), há um direito constitucional difuso a um devido procedimento na elaboração normativa, que deve ser observado por qualquer órgão estatal, Legislativo ou Executivo, que se ocupe da elaboração de normas: todo ato normativo deverá ser acompanhado de uma justificativa pública, que deve abranger razões e informações, e abordar, necessariamente, três temas essenciais: "qual o problema que a norma pretende resolver, qual o resultado final esperado com sua execução e quais os custos e impactos antecipados em consequência da norma. Eventualmente esse procedimento deverá também incluir a participação de interessados e o contraditório dessas razões e dessas informações".

\section{Racionalidade linguística ou comunicativa}

Para Morais (2007, p. 527), a clareza é um dos principais objetivos visados pela Legística Formal, sendo a principal qualidade a ser alcançada na redação e sistematização das leis. Explica o autor que devem ser evitadas disposições ambíguas e imprecisas, bem como conceitos indeterminados, típicos de leis simbólicas, uma vez que a mensagem normativa deve ser transmitida com sucesso aos destinatários.

A racionalidade linguística ou comunicativa (R1) designa o grau em que o legislador ou outra autoridade transmite com sucesso uma dada mensagem normativa aos seus destinatários (OLIVER-LALANA, 2013, p. 140).

Em linhas gerais, a densidade normativa das normas é determinada pelo caráter das disposições (detalhado ou aberto); o tipo de vocábulo (noções jurídicas e definições determinadas ou indeterminadas) e pelas enumerações dos artigos (exaustivas ou exemplificativas) (MADER, 2007, p. 203). 
Cabe ponderar que a discricionariedade não é positiva ou negativa em si, em muitos casos é até necessária para a implementação de políticas públicas, na medida em que permite a contextualização e a adaptabilidade da ação, conforme o público alvo (ANNENBERG, 2013, p. 142; LOTTA, 2015, p. 295). Entretanto, é necessário considerar que a discricionariedade também pode conduzir a uma situação de inércia. Quanto mais genéricos os objetivos definidos nas normas jurídicas que regem o funcionamento das políticas públicas, maior será a possibilidade de influência dos grupos de pressão e mais discricionária será a implementação pelos burocratas que atuam na execução (OLIVEIRA, 2013, p. 26).

É de se notar que as estruturas normativas das Diretrizes Curriculares Nacionais para o curso de graduação em pedagogia, licenciatura (Resolução $\left.\mathrm{CNE} / \mathrm{CP} \mathrm{n}^{\circ} 1 / 2006\right)$ e das Diretrizes Curriculares Nacionais para a formação inicial em nível superior e para a formação continuada (Resolução CNE n² 2/2015), carecem de força normativa cogente.

A Resolução CNE/CP n ${ }^{\circ} 1 / 2006$ é repleta de disposições abertas e genéricas. Prevalecem jargões pedagógicos, períodos extensos, conceitos indeterminados e expressões imprecisas (v.g. "articulação entre conhecimentos científicos e culturais"; "valores éticos e estéticos"; "diferenças de natureza ambientalecológica"; "escolhas sexuais"), o que gera a dispersão da finalidade da norma, como exemplificado pelo trecho transcrito abaixo:

Art. $2^{\circ}[\ldots] \S 1^{\circ}$ Compreende-se a docência como ação educativa e processo pedagógico metódico e intencional, construído em relações sociais, étnico-raciais e produtivas, as quais influenciam conceitos, princípios e objetivos da Pedagogia, desenvolvendo-se na articulação entre conhecimentos científicos e culturais, valores éticos e estéticos inerentes a processos de aprendizagem, de socialização e de construção do conhecimento, no âmbito do diálogo entre diferentes visões de mundo. $\S 2^{\circ} \mathrm{O}$ curso de Pedagogia, por meio de estudos teórico- práticos, investigação e reflexão critica, propiciará: I - o planejamento, execução e avaliação de atividades educativas; II - a aplicação ao campo da educação, de contribuições, entre outras, de conhecimentos como o filosófico, o histórico, o antropológico, o ambiental-ecológico, o psicológico, o linguístico, o sociológico, o político, o econômico, o cultural. Art. $5^{\circ}$ $\mathrm{O}$ egresso do curso de Pedagogia deverá estar apto a: [...] $\mathrm{V}$ reconhecer e respeitar as manifestações e necessidades físicas, cognitivas, emocionais, afetivas dos educandos nas suas relações individuais e coletivas; [...] X - demonstrar consciência da diversidade, respeitando as diferenças de natureza ambientalecológica, étnico- racial, de gêneros, faixas geracionais, classes sociais, religiões, necessidades especiais, escolhas sexuais, entre outras; 
Na visão de Gatti e Barreto (2009, p. 49) a Resolução CNE/CP nº 1/06 é marcada pela "dispersão disciplinar", uma vez não delimita com exatidão a identidade formativa dos licenciados em Pedagogia: "enfeixar todas essas orientações em uma matriz curricular, especialmente para os cursos noturnos onde se encontra a maioria dos alunos, não é tarefa fácil, e está conduzindo a algumas simplificações que podem afetar o perfil dos formados". No mesmo sentido, Saviani (2009) observa que "não é fácil identificar na Resolução do CNE uma orientação que assegure um substrato comum em âmbito nacional a dar um mínimo de unidade" ao curso de pedagogia.

Da mesma forma, as disposições da Resolução CNE/CP n²/2015, apresentam reduzida densidade normativa. Está previsto no ato normativo o "princípio da articulação entre teoria e prática", uma das estratégias contempladas no Plano Nacional de Educação (PNE) de 201422 para a formação de professores (metas 13 e 15), consistente na melhoria da formação docente e valorização das "práticas de ensino e os estágios nos cursos de formação de nível médio e superior dos profissionais da educação, visando ao trabalho sistemático de articulação entre a formação acadêmica e as demandas da educação básica", por meio da combinação da "formação geral e específica com a prática didática".

Entretanto, a Resolução não explicita como se dará efetivamente a referida "articulação", ou seja, pouco avança no estabelecimento de uma identidade própria aos cursos de licenciatura. Faltam diretrizes que conduzam à estruturação dos projetos pedagógicos pelas instituições de ensino e à formulação e implementação de programas governamentais:

Art. $3^{\circ} \mathrm{A}$ formação inicial e a formação continuada destinam-se, respectivamente, à preparação e ao desenvolvimento de profissionais para funções de magistério na educação básica em suas etapas [...] a partir de compreensão ampla e contextualizada de educação e educação escolar, visando assegurar a produção e difusão de conhecimentos de determinada área e a participação na elaboração e implementação do projeto político-pedagógico da instituição, na perspectiva de garantir, com qualidade, os direitos e objetivos de aprendizagem e o seu desenvolvimento, a gestão democrática e a avaliação institucional. [...]§ $5^{\circ}$ São princípios da Formação de Profissionais do Magistério da Educação Básica: [...] $\mathrm{V}$ - a articulação entre a teoria e a prática no processo de formação docente, fundada no domínio dos conhecimentos científicos e didáticos, contemplando a indissociabilidade entre ensino, pesquisa e extensão;

${ }^{22}$ Lei no 13.005 , de 25 de junho de 2014. Ver neste dossiê o artigo de Clarice Seixas Duarte. 
A Resolução CNE $n^{\circ}$ 2/2015 também repete, desnecessariamente, o teor de disposições de outras normas educacionais, como a LDB e o PNE. Com efeito, é possível constatar que as normas produzidas pelo $\mathrm{CNE}$ não satisfazem os requisitos propugnados pela racionalidade linguística, dada a enunciação de diversos valores confusos e desprovidos de lógica.

\section{Racionalidade sistemática ou legal-formal}

A racionalidade legal-formal ou sistemática (R2) está vinculada às premissas extraídas da própria essência do direito, em especial a sistematicidade:

[...] ao interior de um mesmo espaço social, o direito não se pode pensar se não sob a forma de um conjunto coerente de regras, mutuamente compatíveis, regidas por um princípio fundamental de não contradição: toda antinomia insuperável, toda injunção paradoxal, assinalaria a morte do direito, privando-o de seu poderio normativo. Sem dúvida, essa sistematicidade não é jamais dada, mas conquistada continuamente [...]. Se a explosão de um direito pós-moderno, doravante produzido em lugares diversos e sob formas heterogêneas, amplia as dificuldades desse empreendimento, isso a torna mais necessária ainda (CHEVALLIER, 2009, p. 170-171).

Logo, qualquer norma deve ser coerente e logicamente consistente com a ordem jurídica pré-existente (OLIVER-LALANA, 2013, p. 140). No caso da política brasileira de formação de professores, um dos fatores que prejudica a sistematicidade do direito produzido, é a quantidade de centros produtores de normas (v.g. Conselhos Federal e Estadual, Capes, etc.) e de normas produzidas. Somente o CNE, em quinze anos, considerando o período de 1996 a 2011, expediu mais de 13.000 pareceres $^{23}$, com propostas de resoluções (NUNES et al., 2011, p. 13).

Por conta da "poluição legislativa" (MORAIS, 2007, p. 193) e a multiplicidade de temas avaliados pelo órgão, uma primeira dificuldade reside na identificação das categorias normativas que conformam a formação de professores.

Conforme Dourado (2009), a produção normativa do CNE sobre formação de professores abrange, ao menos, quarenta temáticas, regulamentadas de forma dispersa, que podem ser agrupadas em dez macrotemas.

${ }^{23}$ Ainda que os pareceres não tenham funções normativas, contêm propostas de resoluções e balizas interpretativas, que podem direcionar o monitoramento e a avaliação dos efeitos da Resolução. 
PROCESSO DE ELABORAÇÃO NORMATIVA E POLÍTICAS PÚBLICAS: A VISÃO JURÍDICOINSTITUCIONAL DA POLÍTICA DE FORMAÇÃO DE PROFESSORES DA EDUCAÇÃO BÁSICA

Tabela 2: Temas presentes na produção normativa do CNE sobre formação de professores da educação básica

\begin{tabular}{|c|c|c|}
\hline & Macrotemas & Temáticas específicas \\
\hline 1 & $\begin{array}{l}\text { Classificação, conceituação } \mathrm{e} \\
\text { diretrizes }\end{array}$ & $\begin{array}{l}\text { Educação, educação superior, formação dos } \\
\text { profissionais da educação, formação em nível } \\
\text { médio, valorização do magistério, formação inicial } \\
\text { e formação continuada, profissional da educação X } \\
\text { profissional do magistério, funções do magistério. }\end{array}$ \\
\hline 2 & Formação docente: níveis & Níveis superior e médio. \\
\hline 3 & Formação inicial & $\begin{array}{l}\text { Nível médio, graduação, licenciatura, pedagogia, } \\
\text { normal superior. }\end{array}$ \\
\hline 4 & Formação continuada: tipos & $\begin{array}{l}\text { Atualização, aperfeiçoamento, capacitação, } \\
\text { especialização, mestrado, doutorado. }\end{array}$ \\
\hline 5 & Formação docente: ambientes & Formação presencial e a distância \\
\hline 6 & $\begin{array}{l}\text { Formação docente: orientações } \\
\text { curriculares }\end{array}$ & $\begin{array}{l}\text { Aproveitamento de estudos, carga horária/ duração } \\
\text { curso/integralização, diretrizes curriculares e } \\
\text { conteúdos formativos, equivalência de estudos, } \\
\text { projeto formativo ou projeto pedagógico; }\end{array}$ \\
\hline 7 & $\begin{array}{l}\text { Formação docente: instituições } \\
\text { formadoras }\end{array}$ & $\begin{array}{l}\text { Institutos superiores de educação, faculdade, centro } \\
\text { universitário, universidade }\end{array}$ \\
\hline 8 & Formação docente: financiamento & Fundef e Fundeb \\
\hline 9 & $\begin{array}{l}\text { Formação docente: valorização } \\
\text { docente }\end{array}$ & $\begin{array}{l}\text { Condições de trabalho, plano de carreira, } \\
\text { profissionalização e valorização docente, relação } \\
\text { quantitativa professor/aluno, remuneração, } \\
\text { avaliação; }\end{array}$ \\
\hline 10 & $\begin{array}{l}\text { Formação docente: exercício } \\
\text { profissional. }\end{array}$ & $\begin{array}{l}\text { Concurso público; formação em serviço; formação } \\
\text { inicial e continuada; qualidade da atuação docente; } \\
\text { formação dos profissionais do magistério. }\end{array}$ \\
\hline
\end{tabular}

Fonte: adaptado de Dourado (2009)

Parece correto o diagnóstico de que a adoção de procedimentos para a consolidação da legislação é necessária não só pela quantidade de atos normativos, como também pela complexidade das matérias (DOURADO, 2009, p. 8). Entre 1997 
e 2017, após a LDB/1996, foram editadas mais de quarenta resoluções ligadas à formação de professores pelo $\mathrm{CNE}^{24}$.

Com base nos macrotemas identificados por Dourado (2009), foi possível constatar que a temática mais contemplada pelas resoluções do CNE sobre a carreira do magistério é a estrutura curricular, presente em ao menos trinta e uma resoluções, em diferentes níveis de densidade normativa.

A partir da análise das resoluções produzidas pelo CNE no campo de formação de professores, também foi possível identificar que a maior parte das normas é parcialmente desatualizada, caiu em desuso, é sobreposta a outra ou foi implicitamente revogada por legislação superveniente, o que gera incertezas sobre o ato normativo que deve nortear as instituições de ensino e a atividade dos gestores públicos.

Como apontam Nunes, Barroso e Fernandes (2011, p. 13), apesar de sua atuação presente e diversificada, o Conselho Nacional de Educação não faz política governamental estratégica". No mesmo sentido, Bucci e Vilarino (2013, p. 143) afirmam que o CNE "possui reduzido papel de articulação", uma vez que segue uma dinâmica própria de trabalho, "que nada vincula à questão federativa", porém, as autoras advertem que "é recomendável muita cautela antes que se crie mais um órgão a concorrer com tantos outros, acumulando material adicional sobre a panóplia normativa que asfixia a Educação brasileira".

Em algumas resoluções, dissociadas da cadeia normativa pré-existente, não são mencionadas de forma exaustiva as normas revogadas, o que torna tormentosa a identificação das disposições legais aplicáveis. As resoluções das Diretrizes Curriculares Nacionais dos diversos cursos de licenciatura também não têm um ponto de convergência ${ }^{25}$.

É interessante observar que um dos vetores que orientaram a edição da Resolução $n^{\circ}$ 2/2015 foi justamente a necessidade de consolidação das normas nacionais para a formação de profissionais do magistério para a educação básica, porém, seguindo o padrão da maior parte das normas produzidas pelo CNE, está previsto no ato normativo apenas a revogação, não taxativa, de algumas resoluções

\footnotetext{
${ }^{24}$ Foram consideradas apenas as resoluções decorrentes dos pareceres homologados.

25 "Não só os cursos são dispersos, suas Diretrizes Curriculares Nacionais são separadas entre si, na maioria dos casos, pouco específicas, ficando na esteira dos bacharelados, ou, como no caso da licenciatura em Pedagogia, com um volume de funções que são verdadeiramente impossíveis de ser concretizadas em uma formação de 2.800 horas" (GATTI, 2015, p. 239).
} 
e de eventuais disposições em contrário ${ }^{26}$, diferentemente das prescrições contidas na $\operatorname{LC~}^{\circ}{ }^{95} / 1998^{27}$ e na Lei ${ }^{\circ}$ 9.191/201728.

Consideradas as mais de quarenta resoluções relacionadas à formação de professores, entre 1997 e 2017, constata-se que o padrão de atuação do CNE não foi regular, porém, a atuação normativa do órgão foi mais intensa após a formulação de algumas políticas públicas (v.g. Fundeb e lei do piso salarial) e nos períodos imediatamente posteriores à aprovação dos Planos Nacionais de Educação em 2001 e 2014.

Ademais, como constatado por Jorge (2018), o sistema normativo do CNE, de natureza regulatória, é pouco integrado à Capes, agência de fomento que responde não só pela formação de profissionais da educação na pós-graduação, como também, desde a edição da Lei $n^{\circ} 11.502 / 2007$, pela formulação de programas governamentais direcionados para a formação de professores da educação básica, o que aumenta o risco de promoção de ações desencontradas.

Diante da dificuldade do CNE em avançar na disciplina jurídica de questões polêmicas, uma das estratégias é a formulação de programas governamentais como forma de acelerar a inserção de temas ligados à alteração diretrizes curriculares na agenda do CNE e de outras arenas decisórias.

Alguns programas promovidos pela Capes, como o Programa Institucional de Bolsa de Iniciação à Docência (PIBID), baseado na concessão de bolsas de iniciação à docência a alunos de cursos de licenciatura que exerçam atividades pedagógicas em escolas públicas da educação básica ${ }^{29}$ e aos professores responsáveis pela coordenação e supervisão destas atividades (art. $5^{\circ}$ do Decreto $n^{\circ} 7.219 / 2010$ ), apresentam ferramentas pedagógicas voltadas para a formação em serviço e

${ }^{26}$ Art. 25. Esta Resolução entra em vigor na data de sua publicação, revogadas as disposições em contrário, em especial a Resolução CNE/CP n 2, de 26 de junho de 1997, a Resolução CNE/CP n ${ }^{\circ}$ 1, de 30 de setembro de 1999, a Resolução CNE/CP n ${ }^{\circ} 1$, de 18 de fevereiro de 2002 e suas alterações, a Resolução $\mathrm{CNE} / \mathrm{CP} \mathrm{n}^{\circ}$ 2, de 19 de fevereiro de 2002 e suas alteraç̃oes, a Resolução no 1, de 11 de fevereiro de 2009, e a Resolução no 3, de 7 de dezembro de 2012

${ }^{27}$ Art. 9o A cláusula de revogação deverá enumerar, expressamente, as leis ou disposições legais revogadas.

28 "Art. 18. A cláusula de revogação relacionará, de forma expressa, todas as disposições que serão revogadas. §1ำ A expressão "revogam-se as disposições em contrário" não será utilizada"

${ }^{29}$ Art. $3^{\text {o }}$ São objetivos do PIBID: I - incentivar a formação de docentes em nível superior para a educação básica; II - contribuir para a valorização do magistério; III - elevar a qualidade da formação inicial de professores nos cursos de licenciatura, promovendo a integração entre educação superior e educação básica; IV - inserir os licenciandos no cotidiano de escolas da rede pública de educação, proporcionando-lhes oportunidades de criação e participação em experiências metodológicas, tecnológicas e práticas docentes de caráter inovador e interdisciplinar que busquem a superação de problemas identificados no processo de ensino-aprendizagem; V incentivar escolas públicas de educação básica, mobilizando seus professores como coformadores dos futuros docentes e tornando-as protagonistas nos processos de formação inicial para o magistério; e VI - contribuir para a articulação entre teoria e prática necessárias à formação dos docentes, elevando a qualidade das ações acadêmicas nos cursos de licenciatura. 
formação prática nas licenciaturas, porém, tais medidas ficam adstritas ao públicoalvo dos programas.

Um exemplo a ilustrar isso é a organização de seminários de iniciação ao magistério, com a participação dos estudantes bolsistas, coordenadores e supervisores, para que sejam apresentados os resultados alcançados e expostas boas práticas, bem como o acompanhamento e avaliação do projeto institucional e análise de impacto na rede pública de educação básica e nos cursos de formação de professores da própria instituição (art. $5^{\circ}, \S 30$ ). Um mecanismo semelhante poderia ter sido introduzido pelo CNE, por meio da Resolução CNE n ${ }^{\circ}$ 2/2015.

Em 15 de outubro de 2017, o MEC/Capes anunciou o estabelecimento de uma nova Política Nacional de Formação de Professores, que teria como ação central o "Programa de Residência Pedagógica", anunciado pelo governo como uma "modernização" do PIBID, consistente no "estágio supervisionado, com ingresso a partir do terceiro ano da licenciatura, ao longo do curso, na escola de educação básica" (BRASIL, 2017), ou seja, a tentativa de promover maior articulação entre os centros formadores e as redes de ensino.

$\mathrm{Na}$ avaliação da Associação Nacional de Pós-Graduação e Pesquisa em Educação, o "Programa de Residência Pedagógica", amparado em um singelo edital, não pode ser caracterizado como uma nova prática educacional, ao fundamento de que o desenho institucional do programa não é uma efetiva integração entre teoria e prática ${ }^{30}$, mas sim uma separação das duas dimensões, "retomando a velha fórmula observação, participação e regência" (ANPED, 2018, p. 2).

É interessante observar que há apenas uma vaga menção às residências pedagógicas na Resolução CNE/CP n 2/2015 (art. 12, inciso III, 'a'), o que também torna a implementação da medida restrita e focalizada.

\section{Racionalidade pragmática ou social}

O quadro normativo também não satisfaz de forma abrangente as exigências da racionalidade pragmática ou social (R3), correspondente ao grau em que os atos normativos são cumpridos pelos destinatários, têm o impacto comportamental previsto ou são realmente traduzidos em ações ou na implementação da política (OLIVER- LALANA, 2013, p. 140).

Além de não ter sido estabelecido nenhum procedimento específico ou medida indutora para a articulação da formação teórica e prática, o quadro normativo

\footnotetext{
30 "A denominação residência pedagógica, embora possa sugerir uma inserção de estudantes em formação na docência com a indicação de efetiva articulação entre universidades e escolas, recebeu um desenho no Programa que reproduz a lógica de ações parcelarizadas em horas, com atividades previamente definidas que apontam para uma inserção pontual do estudante na prática escolar e, ainda, consolidam uma relação hierárquica e excludente entre "teoria e prática" e "universidade e escola" que sabemos, não estimula democracia ou solidariedade, elementos essenciais para formação e pratica docentes" (ANPED, 2018, p. 2).
} 
produzido pelo CNE é omisso em pontos de relevante impacto social, como a estrutura curricular dos programas de formação a distância.

A falta de conceitos específicos sobre a formação de professores por meio da Educação a Distância facilita a implementação de "modelos industriais" de EaD no segmento educacional privado lucrativo. Nas últimas décadas foi expressivo o aumento dessa modalidade, sobretudo nas instituições privadas.

Conforme dados do Censo da Educação de 2017 (BRASIL, 2018), cerca de 47\% das matrículas em licenciaturas foram registradas em cursos na modalidade a distância. Esse quadro decorre, sobretudo, da disseminação do uso das Tecnologias da Informação e da Comunicação (TICs) nos processos de formação docente, facilitada pela abertura da $\mathrm{LDB}^{31}$ e pela disciplina jurídica da $\mathrm{EaD}$, por meio do Decreto $n^{\circ}$ 5.622, de 19 de dezembro de $2015^{32}$ (MALACHEN, 2015, p. 74).

A Resolução CNE /CES n ${ }^{\circ} 1 / 2016$, que estabelece diretrizes e normas nacionais para a oferta de programas e cursos de educação superior na modalidade a distância apresenta conceitos genéricos de $\mathrm{EaD}$. No que diz respeito à formação para o magistério, a norma apenas indica que profissionais da educação, que atuarem na $\mathrm{EaD}$, devem ter "formação condizente com a legislação em vigor e preparação específica para atuar nessa modalidade educacional" (art. $8^{\circ}$ ), porém, curiosamente, $\mathrm{o}$ ato normativo não delimita a estrutura formativa específica ${ }^{33}$.

É possível que a questão da disciplina jurídica da formação a distancia não tenha sido enfrentada pela ação de grupos de interesse, vinculados ao segmento educacional privado lucrativo, e pelos dissensos sobre a temática.

De um lado, alguns educadores compreendem a formação inicial de docentes a distância como uma forma de barateamento, "desintelectualização" e despolitização do professor, destinada apenas à capacitação técnica, massificação e habilitação legal (formal) ${ }^{34}$, em detrimento de uma qualificação efetiva e

\footnotetext{
${ }^{31}$ Art. 80. O Poder Público incentivará o desenvolvimento e a veiculação de programas de ensino a distância, em todos os níveis e modalidades de ensino, e de educação continuada (...)

${ }^{32}$ Revogado pelo Decreto ${ }^{\circ}$ 9.057, de 25 de maio de 2017, que atualmente regulamenta o art. 80 da LDB.

33 , A utilização de tecnologias educacionais no processo de ensino-aprendizagem requer estratégias específicas: "é fundamental contemplar, no projeto pedagógico, aspectos específicos desses ambientes que levem em consideração: uma linha de construção de conhecimento centrada no aluno; nos aspectos culturais e socioeconômicos; nos meios de acesso dos alunos; um material didático preparado especificamente para essa modalidade; uma dinâmica temporal de evolução do processo pedagógico que incorpore a interação entre os atores do processo (alunos e professores tutores); um desenho adequado da avaliação de aprendizagem e a garantia da infraestrutura operacional compatível com o desenho do projeto pedagógico proposto" (BIELSCHOWSKY, 2006, p. 51).

${ }^{34}$ Para Saviani (2009, p. 41), "[o] ensino a distância, nas condições atuais do avanço tecnológico, é um importante auxiliar do processo educativo. Pode, pois, ser utilizado com muito proveito no enriquecimento dos cursos de formação de professores. Tomá-lo, entretanto, como a base dos cursos de formação docente não deixa de ser problemático, pois arrisca converter-se num
} 
emancipadora (MALACHEN, 2015, p. 206). Por outro lado, existem entendimentos de que a EaD pode contribuir para a interiorização de cursos superiores, proporcionar o acesso à educação em escala ampla, favorecer a difusão de novas metodologias de ensino e facilitar a formação em serviço (ABRUCIO, 2015, p. 15; BUCCI, 2013b, p. 707).

Na visão de Bucci (2013b, p. 707), o desafio para o Poder Público não é "o dilema entre conter ou expandir a oferta" de cursos, mas sim o aprimoramento do aparato burocrático regulatório e dos mecanismos de avaliação dos cursos e instituições superiores $^{35}$. Para a autora (BUCCI, 2013b, p. 714), "a regulação tem o papel de elevar qualitativamente o plano em que se dá a concorrência entre os ofertantes do serviço, não permitindo que a competição baseada no preço seja fator de rebaixamento do nível educacional".

\section{Racionalidade teleológica ou instrumental}

A Racionalidade teleológica ou instrumental, referente à capacidade das leis de atingir os objetivos visados, como aponta Oliver-Lalana (2013, p. 156), pode ser mensurada não só pelo impacto econômico como também pela repercussão social do ato normativo.

Para alguns autores, as exigências da racionalidade teleológica somente serão concretizadas se o conteúdo essencial da norma "for estabelecido através de um debate aberto, onde qualquer ideologia, opinião e interesse tenha a oportunidade de ser expressa e argumentada de acordo com o princípio deliberativo de uma sociedade democrática" (DÍEZ-RIPOLLÉS, 2019, p. 58).

Na mesma linha, Waldron (2016, p. 149) aponta que o "respeito à discordância", contrário à tendência de instituir um consenso artificial, é um dos princípios orientadores do processo legislativo. Outro princípio mencionado pelo autor é a "deliberação responsiva": não basta que seja dada voz a uma variedade de visões dissonantes, sendo necessária a abertura à argumentação, a fim de propiciar a possibilidade de convencimento e eventual mudança de opinião.

Como ressaltam Gatti et al. (2019, p. 69), o ideal que norteou a edição da Resolução CNE/CP n² 2/2015 foi a "justiça social, com respeito à diversidade e promoção da participação e da gestão democrática" (art. 12, inciso II), porém, o próprio processo de elaboração da norma não privilegiou a ampla participação dos atores envolvidos.

A falta de participação dos professores, diretamente afetados pelas proposições do $\mathrm{CNE}$, e de entidades representativas dos diversos segmentos dos profissionais

mecanismo de certificação antes que de qualificação efetiva. Esta exige cursos regulares, de longa duração ministrados em instituições sólidas e organizadas preferencialmente na forma de universidades".

${ }^{35}$ Como afirmado na Conferência Mundial da UNESCO sobre Educação Superior, realizada em Paris, em 2009, a globalização da educação, materializada no uso da EaD e de Tecnologias de Informação e Comunicação, é benéfica, porém, também favorece a expansão de "fábricas de diplomas" (degree mills), o que impõe uma atividade regulatória estratégica (UNESCO, 2009). 
da educação superior nos processos de elaboração normativa torna questionável a legitimidade e limita a adesão e o cumprimento das normas.

Para Bucci e Gomes (2017, p. 281), em tese, os conselhos deveriam ser ambientes para a participação da sociedade civil na governança da educação, porém, na prática, esses espaços funcionam predominantemente como "escritórios burocráticos" e "tornaram-se apenas mais uma estrutura de tomada de decisões a ser integrada ao complexo processo de planejamento e organização da educação". Ademais, algumas vezes "foram capturadas por interesses privados que derrubaram os objetivos públicos que levaram à sua criação" (BUCCI; GOMES, 2017, p. 281).

Cumpre observar que o CNE promoveu uma audiência pública, realizada na Universidade Católica de Pernambuco, para discutir o Projeto de Resolução 23.3.15, que antecedeu a Resolução CNE/CP n ${ }^{\circ}$ 2/2015, porém, em cotejo com o texto final, verifica- se que não foram feitas alterações substanciais, o que pode ser um indicativo de que a audiência pública foi um canal de participação pouco efetivo ${ }^{36}$.

Como se depreende da ata da audiência (ata no 9, de 6 de abril de 2015), a audiência, na verdade, foi a segunda parte de uma "reunião itinerante" do Conselho Pleno do CNE, com pouca ou reduzida deliberação ${ }^{37}$, de modo que o propósito foi apenas a legitimação formal da norma, o que demonstra que a realização de audiências pública na Administração Pública depende do estabelecimento de critérios transparentes e de outros requisitos específicos para organização de seu procedimento.

Não consta na ata nenhuma informação sobre as discussões feitas na "parte dedicada à audiência pública". Constata-se que a maior parte dos presentes eram autoridades políticas e dirigentes de instituições de ensino superior privadas. Os educadores, atores diretamente interessados na edição da norma, não tiveram suas demandas vocalizadas, o que mitiga a legitimidade social do processo de elaboração da norma.

\footnotetext{
${ }^{36} \mathrm{O}$ áudio da audiência pública e a ata do encontro, utilizados na análise, foram obtidos por meio do Sistema Eletrônico do Serviço de Informação ao cidadão do governo federal, com fundamento na Lei de Acesso à Informação (Lei no 12.527/2011). Seria desejável que todas as informações e contribuições expostas no evento tivessem sido disponibilizadas no endereço eletrônico do CNE. Para Barcellos (2017, p. 199), as justificativas e estudos que originaram proposições normativas devem estar permanentemente disponíveis em bancos de dados digitais não só pela necessidade de publicidade como também pela memória das justificativas. Ademais, a facilitação do acesso às informações que embasaram a edição da lei favorece o estabelecimento de indicadores e metas para o monitoramento dos resultados esperados.

${ }^{37}$ Como esclarece Morais (2017, p. 120), a noção de deliberação impõe "no campo legiferante, que o legislador deva fundar as normas que propõe e aprova, em razões argumentativas consistentes que respondam a razões contrárias ou diversas, oriundas não apenas de outras instituições mas dos próprios cidadãos. Atos legislativos que careçam de um adequado processo argumentativo no espaço público careceriam de legitimação política" (MORAIS, 2017, p. 120).
} 
Para Morais (2007, p. 499), a adoção de mecanismos de participação como fase consultiva da análise prévia de impacto das leis possibilita um melhor dimensionamento do problema que norteou a decisão de legislar, o conhecimento das reações dos grupos de interesse envolvidos e a remoção de encargos desnecessários sobre os destinatários.

Entretanto, se é verdade que as audiências e consultas públicas têm potencial para mitigar a assimetria representativa e facilitar o controle social, o fato é que acabam participando do processo decisório os grupos econômicos mais estruturados e efetivamente interessados, com maior acesso à informação, o que legitima, muitas vezes, cenários decisórios participativos artificializados.

\section{Racionalidade ético-moral ou axiológica}

Finalmente, é possível constatar que o quadro normativo não satisfaz plenamente as exigências da racionalidade axiológica, uma vez que não há um enfrentamento consistente e sistêmico da falta de atratividade da carreira docente, que não é determinada apenas pela questão formativa ${ }^{38}$. A baixa atratividade econômica da carreira e condições precárias de trabalho também prejudicam a qualidade da formação docente.

Para Ximenes (2014, p. 140), a definição do conteúdo de princípios constitucionais da educação, como o princípio da qualidade de ensino, não é axiologicamente neutra, de modo que a conexão do direito educacional com as pretensões normativas, de caráter amplo, dos direitos humanos no campo educacional requer uma concepção de direito que contemple "o fortalecimento da agenda distributiva, ainda que limitada, do Estado Social".

Para Saviani (2017, p. 72), as condições de trabalho docente das escolas também impactam na formação porque o processo formativo tem como uma de suas referências a rede escolar onde os estágios serão realizados e, sobretudo, estão ligadas diretamente ao valor social da profissão:

se as condições de trabalho são precárias, isto é, se o ensino se realiza em situação difícil e com remuneração compensadora, os jovens não terão estímulo para investir tempo e recursos numa formação mais exigente e de longa duração. Em consequência, os cursos de formação de professores terão de trabalhar com alunos desestimulados e pouco empenhados, o que se refletirá negativamente em seu desempenho.

Como exposto no gráfico 1, poucas normas produzidas pelo CNE foram voltadas para a valorização da carreira ou melhoria das condições de trabalho dos

\footnotetext{
38 Ver neste dossiê o artigo de Carlos Toledo, que discute questões do federalismo educacional e do plano de carreira dos professores.
} 
professores. Para ilustrar esse ponto, pode ser mencionada a revogação do parecer CNE/CEB nº 8/2010, que tinha como projeto de resolução o estabelecimento do Custo Aluno Qualidade inicial (CAQi), matriz de referência de padrões mínimos de qualidade para a Educação Básica que deveriam nortear a alocação orçamentária e a promoção de políticas públicas pelos agentes públicos, proposto pela Campanha Nacional pelo Direito à Educação, movimento da sociedade civil (PINTO, 2013, p. 290).

Além dos custos com pessoal, bens e serviços, equipamentos, materiais e características dos prédios de escola (PINTO, 2013, p. 293), o CAQi tem como variável a remuneração dos professores, compatível com a de outros profissionais com igual nível de formação ${ }^{39}$. Entretanto, o parecer, com a proposta de resolução, não foi homologado pelo Ministro da Educação, sobretudo porque seria necessária maior complementação da União ao Fundeb (FINEDUCA, 2013).

Vale notar que conforme o PNE de 2014, o CAQi, uma das estratégias da meta 20, correspondente à ampliação do investimento em educação pública, deveria ter sido implementado até o ano de $2016^{40}$. Ou seja, nem mesmo o fato de que o CAQi tenha sido previsto como parâmetro de financiamento de políticas públicas educacionais no PNE e deliberado no âmbito do CNE garantiu a homologação do parecer.

A avaliação do quadro normativo revela que a necessidade de alterações efetivas na política de formação de professores e de valorização da carreira docente está presente na agenda governamental (sentido amplo) porém, não foi consolidada na "agenda decisional": enquanto a agenda governamental diz respeito a lista de assuntos que estão recebendo atenção dos atores governamentais, a

\footnotetext{
${ }^{39}$ Vários dispositivos da Resolução contemplam a valorização salarial e social da profissão: Art. $3^{\circ}$ Vencer o desafio da valorização dos profissionais da educação exige valorizar sua remuneração, instituir planos de carreira, promover formação inicial e continuada e propiciar adequadas condições de trabalho. $\S 1^{\circ}$ A remuneração dos professores deve ser compatível com a de outros profissionais com igual nível de formação. $\S 2^{\circ}$ A valorização dos professores exige compatibilização de remuneração, a partir do piso salarial profissional nacional do magistério público. $\S 3^{\circ}$ As medidas de valorizacạao do magistério devem tornar a carreira docente mais atraente para os egressos do Ensino Médio. Art. $4^{\circ}$ Deve-se implementar jornada de 40 (quarenta) horas semanais para os profissionais da educação, em tempo integral em uma mesma escola, com demais condições adequadas de trabalho e infraestrutura. (...) Art. $8^{\circ}$ No contexto do CAQi, os padrões mínimos podem ser definidos como aqueles que levam em conta, entre outros parâmetros: I - professores e pessoal de apoio técnico e administrativo que assegurem o bom funcionamento da escola, com remuneração adequada; II - Creches e escolas que possuam condições de infraestrutura e de equipamentos adequados; III - definição de relação adequada entre número de alunos por turma e por professor, e número de salas e de alunos.

${ }^{40}$ Estratégia 20.6: “20.6) no prazo de 2 (dois) anos da vigência deste PNE, será implantado o Custo Aluno-Qualidade inicial - CAQi, referenciado no conjunto de padrões mínimos estabelecidos na legislação educacional e cujo financiamento será calculado com base nos respectivos insumos indispensáveis ao processo de ensino-aprendizagem e será progressivamente reajustado até a implementação plena do Custo Aluno Qualidade - CAQ".
} 
agenda de decisões abrange a lista de temas dentro da agenda governamental que é efetivamente enfrentada pelos formuladores de políticas públicas (KINGDON, 2014, p. 4$)^{41}$.

A produção normativa do CNE, marcada pelo simbolismo, reflete a falta de consenso sobre o modelo de formação de professores. Segundo Marcelo Neves (2011, p. 54), uma das características da legislação simbólica é a aparente conciliação entre propósitos antagônicos, que implica na manutenção do status quo e é uma forma de "adiar conflitos políticos sem resolver realmente os problemas sociais subjacentes". A lei simbólica visa mostrar que o governo "entendeu o problema", que "algo foi feito" (KARPEN, 2016, p. 305).

Ademais, como enfatizam Ranieri e Alquéres (2012, p. 12), a exigência de homologação das deliberações e pronunciamentos do CNE pelo Ministro de Estado da Educação (art. $2^{\circ}$ da Lei 9.131/1995) mitiga o desenvolvimento efetivo e independente das competências do CNE:

Como se pode observar, em relação às competências normativas do CNE, pouco espaço há para o seu desenvolvimento efetivo e independente, ante a exigência de homologação de todas as suas deliberações e pronunciamentos pelo Ministro de Estado da Educação (art. $2^{\circ}$ da Lei 9.131/1995), embora a própria lei, em seu art. $9^{\circ}$, caput, assegure decisões privativas e autônomas às suas Câmaras [...] O que ocorre, na verdade, é a subordinação do CNE ao MEC, especialmente em matéria de avaliação e controle na educação superior, podendo-se deduzir que o Conselho nada mais é se não um órgão de assessoramento do Ministério.

Assim, o padrão de interação do conselho é marcado pelo conflito e influi na política educacional com dificuldade, dadas as "indefinições e concorrência de funções" com o MEC (DRAIBE, 1998, p. 14) e com a Capes, o que compromete a

\footnotetext{
41 "As agendas governamentais -as listas de temas que são alvo de séria atenção por parte de funcionários do governo- podem ser estabelecidas exclusivamente por atores visíveis, tendo em vista somente a dinâmica dos problemas ou da política. Por exemplo, funcionários do governo podem se dedicar a um problema importante, sem achar solução para ele. Políticos podem também destacar um assunto, sem que haja um problema ou solução. Uma agenda de decisões- a lista de temas que é alvo de deliberação-, como a promulgação de lei ou uma escolha presidencial, é estabelecida de modo diferente. A probabilidade que um item tem de tornar-se prioritário numa agenda de decisões aumenta significativamente se todos os três elementos - problema, proposta de políticas públicas e receptividade na esfera política- estiverem ligados em um único pacote. Por outro lado, conexões parciais têm menos chances de ganhar prioridade dentro de uma agenda de decisões. Por exemplo, os problemas que chegam às agendas de decisões sem propostas de soluções não têm as mesmas chances de serem deliberados do que aqueles que incluem propostas de soluções. E propostas sem apoio político têm menos probabilidade de serem decididas do que aquelas que têm esse apoio" (KINGDON, 2014, p. 202).
} 
produção de normas coerentes. O processo de elaboração normativa do CNE também é pouco articulado com os governos subnacionais, que recebem os professores em suas redes de ensino.

\section{CONSIDERAÇÕES FINAIS E ENCAMINHAMENTOS}

Como exposto, a abordagem DPP possibilita a estruturação de um trabalho genuinamente interdisciplinar, para além da norma posta. A compreensão do fenômeno governamental "por dentro do direito" (BUCCI, 2013a, p. 36), com os instrumentais da Legística, tornou possível a constatação de que não há no quadro normativo que sustenta a formação de professores uma identidade formativa clara, capaz de promover a valorização da carreira. Faltam medidas indutoras e padrões que conduzam à incorporação das prescrições normativas aos currículos dos cursos de licenciaturas.

Não é possível afirmar que as principais normas (LDB, Resoluções do CNE, etc.) tenham gerado, no caso da política de formação docente, um regime de efeitos jurídicos, uma cadeia normativa marcada pela "sucessão de atos encadeados ou combinados, cujo nexo são efeitos com significado jurídico e social particular" (BUCCI, 2013a, p. 258), o que compromete a implementação de políticas públicas de formação docente.

No caso das normas do CNE, é ausente a definição precisa dos objetivos e resultados esperados com a edição das normas, o que impede uma concepção sistemática das Diretrizes Curriculares Nacionais para a formação inicial e continuada de professores. Como visto, uma das questões recorrentemente mencionada na literatura educacional é a articulação entre teoria e prática, porém, não foi especificado no quadro normativo como tal medida deve ser materializada.

Ainda que o CNE seja um órgão especializado, de natureza consultiva e deliberativa, ligado ao Poder Executivo, possui uma agenda pouco autônoma, influenciada pela dinâmica política, sobretudo pela forma de nomeação de seus conselheiros, arranjo institucional que pouco contribui para a redução das tensões entre os grupos de interesse (educadores, representantes do segmento privado com fins lucrativos, sindicatos, etc.).

O Conselho, que deveria ter um papel normativo suplementar, na densificação das proposições Poder Legislativo, ou, no mínimo, doutrinário, com o estabelecimento de orientações e diretrizes sobre as formas de interpretação e aplicação das normas em seus pareceres, produziu um quadro normativo que favoreceu a flexibilização da atuação das instituições de ensino superior, dado o elevado grau de indeterminação dos conceitos indicados nos atos normativos.

Além de repensar o modelo institucional do CNE, dada a concorrência de funções com instituições vinculadas ao MEC, é imprescindível, no plano normativo, a consolidação dos atos legais que disciplinam a formação docente, por meio do estabelecimento de "leis quadros" da carreira do magistério, com a 
definição de eixos centrais da formação de professores (v.g. competências e habilidades) e dos planos de carreira, a fim de conferir identidade própria aos cursos de licenciatura.

Também deve ser avaliada a utilização de mecanismos de incentivo, como o delineamento da estrutura formativa de "residências docentes" e a efetiva implementação do modelo; a utilização de prova nacional para ingresso na carreira docente, como mecanismo de indução à mudança dos currículos; o condicionamento de repasse de recursos federais à reforma curricular dos cursos de licenciatura; a aproximação das instituições formadoras e escolas e o fortalecimento dos mecanismos de avaliação das instituições de ensino.

As experiências exitosas de alguns programas da Capes também podem ser universalizadas pela legislação. De qualquer forma, contudo, o êxito da política pública de formação de professores da educação básica requer um enfrentamento sistêmico, que considere fatores como a atratividade da carreira, diretamente ligada à valorização salarial e às condições de trabalho, na forma projetada pela Constituição Federal de 1988.

\section{REFERÊNCIAS}

ABRUCIO, Fernando Luiz (coord.). Formação de Professores no Brasil:

diagnóstico, agenda de políticas e estratégias para mudança. São Paulo: Moderna, 2016.

ANNENBERG, Flávia Xavier. Direito e Políticas Públicas: uma análise crítica de abordagens tradicionais do Direito Administrativo a partir de um estudo do programa Bolsa-Família. 2014. Dissertação (Mestrado em Direito) - Faculdade de Direito, Universidade de São Paulo, São Paulo, 2014.

ANPED. A Política de Formação de Professores no Brasil de 2018: uma análise dos Editais CAPES de Residência Pedagógica e PIBID e a reafirmação da Resolução CNE/ CP 02/2015. Documento apresentado pela ANPED em Audiência do CNE em 09 de abril de 2018. Disponível em http://www.anped.org.br/sites/default/files/images/formacaoprofessores_anpe d_final.pdf. Acesso em 18 jan 2019.

ATIENZA, Manuel. Legislation and argumentation: towarfs a model for the analysis of legislative reasoning. In: OLIVER-LALANA, A. Daniel (ed.).

Conceptions and Misconceptions of Legislation. Suíça: Springer, 2019, p. 175206. 
BACHUR, João Paulo. Federalismo, desigualdades regionais e o municipalismo incompleto: notas para o regime de colaboração na educação. In: MENDES, Gilmar Ferreira; CARNEIRO, Rafael Araripe (coord.). Gestão Pública e Direito Municipal: tendências e desafios. São Paulo: Saraiva, 2016, p. 356-386.

BALDWIN, Robert. Rules and Government. Nova York: Oxford, 1995.

BARCELLOS, Ana Paula de. Direitos Fundamentais e Direito à Justificativa: Devido Procedimento na Elaboração Normativa. 2 ed. Belo Horizonte: Fórum, 2017.

BAR-SIMAN-TOV, Ittai. The global revival of Legisprudence: a compartive view on legislation in legal educacion and research. In: OLIVER-LALANA, A. Daniel (ed.). Conceptions and Misconceptions of Legislation. Suíça: Springer, 2019, p. 275-294.

BEZERRA, Giselle Gomes. Desenho jurídico-institucional da participação social: uma análise do Conselho Nacional de Educação. 2017. Dissertação (Mestrado em Direito) - Faculdade de Direito, Universidade de São Paulo, São Paulo, 2017.

BRASIL. Instituto Nacional de Estudos e Pesquisas Educacionais Anísio Teixeira. Censo da Educação de 2017. Divulgação dos principais resultados. Brasília: Diretoria de Estatísticas Educacionais, 2018. Disponível em:<portal.mec.gov.br/docman/setembro-2018-pdf/97041-apresentac-a-o-censosuperior-u-ltimo/file>. Acesso em: $10 \mathrm{dez} .2019$.

BRUNS, Barbara; LUQUE, Javier (org.). Professores Excelentes: como melhorar a aprendizagem dos estudantes na América Latina e no Caribe. Washington: The World Bank Group, 2015. Disponível em: <https://openknowledge.worldbank.org/handle/10986/20488>. Acesso em 07 Jun.2016. Acesso em: 10 dez. 2019.

BUCCI, Maria Paula Dallari. Direito Administrativo e Políticas Públicas. São Paulo: Saraiva, 2002.

BUCCI, Maria Paula Dallari. Direito e Políticas Públicas: método e aplicações. No prelo, 2019a. 
BUCCI, Maria Paula Dallari. Fundamentos para uma teoria jurídica das políticas públicas. São Paulo: Saraiva, 2013.

BUCCI, Maria Paula Dallari. Notas para uma metodologia jurídica de análise de políticas públicas. In: FORTINI, Cristina; ESTEVES, Júlio César dos Santos; DIAS, Maria Tereza Fonseca (org.). Políticas Públicas- possibilidades e limites. Belo Horizonte: Editora Fórum, 2008, p. 225-260.

BUCCI, Maria Paula Dallari. O art. 209 da Constituição 20 anos depois. Estratégias do Poder Executivo para a efetivação da diretriz da qualidade da educação superior. Fórum Administrativo: Direito Público, Belo Horizonte, v. 9, n. 105, nov. 2009.

BUCCI, Maria Paula Dallari. O conceito de política pública em direito. In: BUCCI, Maria Paula Dallari (org.). Políticas Públicas: reflexões sobre o conceito jurídico. São Paulo: Saraiva, 2006, p. 1-49.

BUCCI, Maria Paula Dallari. Pesquisa em direito e políticas públicas. In: QUEIROZ, Rafael Mafei Rabelo; FEFERBAUM, Marina (coord.). Metodologia da Pesquisa em Direito: técnicas e abordagens para elaboração de monografias, dissertações e teses. 2 ed. São Paulo: Saraiva, 2019b, p. 361-377.

BUCCI, Maria Paula Dallari. Processo administrativo eletrônico e informação pública. O sistema e-MEC e o marco regulatório da educação superior. In: MARQUES NETO, Floriano de Azevedo et al. (org.). Direito e Administração Pública: estudos em homenagem a Maria Sylvia Zanella Di Pietro. São Paulo: Atlas, 2013b, p. 700-725.

BUCCI, Maria Paula Dallari. Quadro de referência de uma política pública: primeiras linhas de uma visão jurídico-institucional. In: SMANIO, Gianpaolo Poggio; BERTOLIN, Patrícia Tuma Martins; BRASIL, Patrícia Cristina (org.). O Direito na fronteira das políticas públicas. São Paulo: Páginas e Letras, 2015, p. 7-11.

BUCCI, Maria Paula Dallari; COUTINHO, Diogo R.. Arranjos jurídicoinstitucionais da política de inovação tecnológica: uma análise baseada na abordagem de direito e políticas públicas. In: COUTINHO, Diogo R.; FOSS, Maria Carolina; MOUALLEM, Pedro Salomon B (org.). Inovação no Brasil: avanços e desafios jurídicos e institucionais. São Paulo: Blucher, 2017, p. 313-340. 
PROCESSO DE ELABORAÇÃO NORMATIVA E POLÍTICAS PÚBLICAS: A VISÃO JURÍDICOINSTITUCIONAL DA POLÍTICA DE FORMAÇÃO DE PROFESSORES DA EDUCAÇÃO BÁSICA

BUCCI, Maria Paula Dallari; GOMES, Fernando Alves. A piece of legislation for the guidance of public education policies in Brazil: the National Education Plan 2014-2024. The Theory and Practice of Legislation, v. 5, 2017, p. 277-301.

BUCCI, Maria Paula Dallari; VILARINO, Marisa Alves. A ordenação federativa da Educação brasileira e seu impacto sobre a formação e o controle das políticas educacionais. In: ABMP; TODOS PELA EDUCAÇÃO (org.). Justiça pela qualidade na educação. São Paulo: Saraiva, 2013, p. 117-150.

CHEVALLIER, Jacques. O Estado Pós-Moderno. Trad. Marçal Justen Filho. Belo Horizonte: Fórum, 2009.

CLÈVE, Clèmerson Merlin. Atividade Legislativa do Poder Executivo. 3 ed. São Paulo: Editora Revista dos Tribunais, 2013.

COSTIN, Cláudia. Educação como política pública. In: MENDES, Gilmar Ferreira; PAIVA, Paulo (org.). Políticas Públicas no Brasil: uma abordagem institucional. São Paulo: Saraiva, 2017, p. 233-260.

COUTINHO, Diogo R. O Direito nas Políticas Públicas. In: SUNDFELD, Carlos Ari; JURKSAITIS, Guilherme Jardim (org.). Contratos Públicos e Direito Administrativo. São Paulo: Malheiros, 2015, p. 447-480.

DELLEY, Jean-Daniel. Pensar a Lei. Introdução a um Procedimento Metódico. Cadernos da Escola do Legislativo. Belo Horizonte, v. 7, n. 12, jan-jun.2004.

DÍEZ-RIPOLLÉS, José Luis. Rationality in criminal law making, rational decision making in a complex socio-legislative process. In: OLIVER-LALANA, A. Daniel (ed.). Conceptions and Misconceptions of Legislation. Suiça: Springer, 2019, p. 51-80.

DOURADO, Luiz Fernandes. Documento C: Consolidação das normas do CNE sobre formação de professores. In: UNESCO. PROJETO 914BRA1123 - CNEPolíticas Educacionais: Subsídio à Formulação e Avaliação de Políticas Educacionais Brasileiras. 2009.

DUARTE, Clarice Seixas. Os entraves à institucionalização do SNE: uma análise a partir da metodologia de pesquisa jurídica em políticas públicas. Revista Estudos Institucionais. v. 5, n. 3, 2019. 
DUARTE, Clarice Seixas. Para além da judicialização: a necessidade de uma nova forma de abordagem das políticas públicas. In: SMANIO, Gianpaolo Poggio; BERTOLIN, Patrícia Tuma Martins; BRASIL, Patrícia Cristina (org.). O Direito na fronteira das políticas públicas. São Paulo: Páginas e Letras, 2015, p. 13-22.

FINEDUCA. Nota Técnica 01/2013: Por que a União deve complementar o CAQi no PNE? Cálculo do quanto a União deve complementar os recursos do FUNDEB para garantir um padrão mínimo de qualidade a todos/as os/as estudantes da educação básica. Disponivel em: <www.redefinanciamento.ufpr.br/nota1_13.pdf >. Acesso em: 15 maio 2019.

FLÜCKIGER, Alexandre; DELLEY, Jean-Daniel. A elaboração racional do direito privado: da codificação à Legística. Cadernos da Escola do Legislativo, Belo Horizonte, v. 9, n. 14, jan-dez. 2007, p. 35-57.

FLÜCKIGER, Alexandre. La planification: un mode de rationalité dépassé pour la Légistique? In: MORAND, Charles-Albert (org.). Légistique formelle et matérielle. Formal and material legistique. Aix-em-Provence: Universitaires D’Aix-Marseille, 1999, p. 117-138.

FLÜCKIGER, Alexandre. (Re)faire la loi: traité de légistique à l'ère du droit souple. Suiça: Stämpfli, 2019.

GATTI, Bernardete Angelina. Formação de professores no Brasil: características e problemas. Educação e Sociedade, Campinas, v. 31, n. 113, dez. 2010.

GATTI, Bernardete Angelina. Formação de professores: compreender e revolucionar. In: SILVA JÚNIOR, Celestino Alves da et al. (org.). Por uma revolução no campo de formação de professores. São Paulo: UNESP, 2015.

GATTI, Bernardete Angelina. Educação, escola e formação de professores: políticas e impasses: políticas e impasses. Educar em Revista, n. 50, 2013.

GATTI, Bernardete Angelina; BARRETO, Elba Siqueira de Sá; ANDRÉ, Marli Eliza de Afonso (org.). Políticas docentes no Brasil: um estado da arte. Brasília: UNESCO, 2011.

GATTI, Bernardete; BARRETO, Elba Siqueira de Sá. Professores do Brasil: impasses e desafios. Brasília: UNESCO, 2009. 
PROCESSO DE ELABORAÇÃO NORMATIVA E POLÍTICAS PÚBLICAS: A VISÃO JURÍDICOINSTITUCIONAL DA POLÍTICA DE FORMAÇÃO DE PROFESSORES DA EDUCAÇÃO BÁSICA

GATTI, Bernardete; BARRETO, Elba Siqueira de Sá; ANDRÉ, Marli Eliza Dalmazo Afonso de; ALMEIDA, Patrícia Cristina Albieri de Almeida. Professores do Brasil: novos cenários de formação. Brasília: UNESCO, 2019.

GOMIDE, Alexandre de Ávila; PIRES, Roberto Rocha C. Capacidades estatais e democracia: a abordagem dos arranjos institucionais para análise de políticas públicas. In: GOMIDE, Alexandre de Ávila; PIRES, Roberto Rocha C. (ed.). Capacidades estatais e democracia: arranjos institucionais de políticas públicas. Brasília : Ipea, 2014.

HOWLETT, Michael; RAMESH, M.; PERL, Anthony. Políticas Públicas: seus ciclos e subsistemas- uma abordagem integral. Trad. Francisco Heidemann. Rio de Janeiro: Elsevier, 2013.

IMMERGUT, Ellen M. O núcleo teórico do novo institucionalismo. In: SARAVIA, Enrique; FERRAREZI, Elisabete (org.). Politicas Públicas: coletânea. Brasília: Escola Nacional de Administração Pública, 2007. v. 1.

JORGE, Ighor Rafael de. A atividade normativa do Poder Executivo: análise da política brasileira de formação de professores da educação básica. In: IX Congresso Internacional da AbrasD: Sociedades pós-constitucionais: a sociologia do direito após 30 anos de constituição cidadã. Homenagem a José Eduardo Faria. 2018. Anais. São Paulo: AbrasD, 2018a.

JORGE, Ighor Rafael de. A dimensão normativa das políticas públicas: a política de formação de professores no Brasil. 2018. Dissertação (Mestrado em Direito) Faculdade de Direito, Universidade de São Paulo, São Paulo, 2018b.

KARPEN, Ulrich. Efficacy, Effectiveness, Efficiency: From Judicial to Managerial Rationality. In: MEßERSCHMIDT, Klaus; OLIVER-LALANA, A. Daniel (ed.). Rational Lawmaking under Review: Legisprudence According to the German Federal Constitutional Court. Suiça: Springer, 2016, p. 295-313.

KINGDON, John W. Agendas, alternatives and public policies. 2 ed. Reino Unido: Pearson, 2014.

LIBÂNEO, José Carlos. Didática. 2 ed. São Paulo: Cortez, 2013. 
LOTTA, Gabriela Spanghero. Burocracia e implementação de políticas de saúde: os agentes comunitários na Estratégia Saúde da Família. Rio de Janeiro: Editora Fiocruz, 2015.

LOUZANO, Paula; MORICONI, Gabriela. Initial teacher education: vision of teaching and characteristics of teacher education programs. In: OREALC; UNESCO (org.). Critical issues for formulating new teacher policies in Latin America and the Caribbean: the current debate. Santiago, Chile: UNESCO, 2015, p. 8-46.

LOUZANO, Paula; ROCHA, Valéria; MORICONI, Gabriela; OLIVEIRA, Romualdo Portela de. Quem quer ser professor? Atratividade, seleção e formação docente no Brasil. Estudos em avaliação educacional, v. 21, n.47, 2010, p. 543-568.

MADER, Luzius. Painel 2- Legística: história e objeto, fronteiras e perspectivas. In: MINAS GERAIS. Assembleia Legislativa do Estado de Minas Gerais. Congresso Internacional de Legística: qualidade da lei e desenvolvimento. Belo Horizonte: Assembleia Legislativa do Estado de Minas Gerais, 2009, p. 43-54.

MALANCHEN, Julia. Políticas de formação de professores a distância no Brasil: uma análise crítica. Campinas: Autores Associados, 2015.

MARQUES, Eduardo. Path Dependence. In: DI GIOVANNI, Geraldo; NOGUEIRA, Marco Aurélio (org.). Dicionário de Políticas Públicas. 2 ed. São Paulo: Editora da Unesp; Fundap, 2015, p. 663.

MARQUES, Eduardo; SOUZA, Celina. Políticas Públicas no Brasil: avanços recentes e agenda para o futuro. In: AVRITZER, Leonardo; MILANI, Carlos R. S.; BRAGA, Maria do Socorro (org.). A Ciência Política no Brasil: 1960-2015. Rio de Janeiro: FGV Editora, 2016, p. 321-345.

MENDES, Gilmar Ferreira. Questões Fundamentais de Técnica Legislativa. Revista Eletrônica sobre a Reforma do Estado (RERE), n. 11, 2007. Disponível em: <http://www.direitodoestado.com.br/artigo/gilmar-mendes/questoesfundamentais-de-tecnica-legislativa>. Acesso em: 12 fev. 2017.

MORAIS, Carlos Blanco de. As Leis Reforçadas: as leis reformadas pelo procedimento no âmbito dos critérios estruturantes das relações entre actos legislativos. Coimbra: Coimbra Editora, 1998. 
PROCESSO DE ELABORAÇÃO NORMATIVA E POLÍTICAS PÚBLICAS: A VISÃO JURÍDICOINSTITUCIONAL DA POLÍTICA DE FORMAÇÃO DE PROFESSORES DA EDUCAÇÃO BÁSICA

MORAIS, Carlos Blanco de. Manual de Legística. Critérios científicos e técnicos para legislar melhor. Lisboa: Verbo, 2007.

NEVES, Marcelo. A Constitucionalização simbólica. 3 ed. São Paulo: WMF Martins Fontes, 2011.

NUNES, Edson; BARROSO, Helena Maria; FERNANDES, Ivanildo. Do CNE ao CNE: 80 anos de política regulatória. Documento de Trabalho n. 99. Rio de Janeiro: Observatório Universitário, 2011. Disponível em:

http://www.observatoriouniversitario.org.br/documentos_de_trabalho/document os_de_trabalho_99.pdf. Acesso em: 12 out. 2017.

OCDE. Teachers Matter: Atracting, Developing and Retaining Effective Teachers - Pointers for Policy Development. Paris: OCDE, 2011. Disponível em: < http://www.oecd.org/education/school/48627229.pdf>.

OLIVEIRA, Vanessa Elias de. As fases do processo de políticas públicas. In: MARCHETTI, Vitor (org.). Políticas Públicas em debate. São Bernardo do Campo: UFABC, MP Editora, 2013.

OLIVER-LALANA. A. Daniel. Rational Lawmaking and Legislative Reasoning in Parliamentary Debates. In: WINTGENS, Luc J.; OLIVER-LALANA, A. Daniel (ed.). The Rationality and Justification of Legislation: essays in Legisprudence. Suiça: Springer, 2013, p. 135-184.

PAULA, Felipe de. Avaliação Legislativa no Brasil: limites e possibilidades. 2016. Tese (Doutorado em Direito) - Faculdade de Direito, Universidade de São Paulo, São Paulo, 2016.

PIERSON, Paul. Increasing Returns, Path Dependence, and the Study of Politics. American Political Science Review, v.94, n.2, p.251-267, 2000.

PINTO, José Marcelino de Rezende. Novas fontes de financiamento e o Custo Aluno-Qualidade (CAQ). In: ABMP; TODOS PELA EDUCAÇÃO (org.). Justiça pela qualidade na educação. São Paulo: Saraiva, 2013, p. 288-311.

RANIERI, Nina Beatriz Stocco; ALQUERES, H. O Conselho Estadual de Educação de São Paulo e a Lei de Diretrizes e Bases da Educação. Lei 9.394/1996. Revista de Direito Educacional, v. 5, p. 295-380, 2012. 
RANIERI, Nina Beatriz Stocco. O Estado de Democrático de Direito e o sentido da exigência de preparo da pessoa para o exercício da cidadania, pela via da educação. 2009. Tese (Livre Docência em Direito) - Faculdade de Direito, Universidade de São Paulo, São Paulo, 2009.

SAVIANI, Dermeval. PDE -Plano de Desenvolvimento da Educação. Análise crítica da política do MEC. Campinas: Autores Associados, 2009.

SAVIANI, Dermeval. Pedagogia: o espaço da educação na universidade. Cadernos de Pesquisa, São Paulo v. 37, n. 130, p. 99-134, Abr. 2007. Disponível em:

$<$ http://www.scielo.br/scielo.php?script=sci_arttext\&pid=S0100-

15742007000100006\&lng =en\&nrm=iso >. Acesso em 23 ago. 2017.

\section{SAVIANI, Dermeval. Sistema Nacional de Educação e Plano Nacional de}

Educação: significado, controvérsias e perspectivas. 2 ed. Campinas: Autores Associados, 2017.

SIECKMANN, Jan. Legislation as Implementation of Constitutional Law: A Foundation for the Demand of Legislative Rationality. In: WINTGENS, Luc J.; OLIVER-LALANA, A. Daniel (ed.). The Rationality and Justification of Legislation: essays in Legisprudence. Suiça: Springer, 2013, p. 107-123.

SIMIELLI, Lara Elena Ramos. Equidade e Oportunidades Educacionais: O Acesso a Professores no Brasil. Arquivos Analíticos de Políticas Educativas, v. 25, n. 46, 2017.

TODOS PELA EDUCAÇÃO. Profissão Professor. 2018. Disponível em: $<$ https://www.todospelaeducacao.org.br/pag/iniciativa-profissao-professor>. Acesso em: 14 abr.2019.

TOLEDO, Carlos José Teixeira de. O neoinstitucionalismo histórico como método de análise jurídica de políticas públicas: o caso da política de carreira docente.

Revista Estudos Institucionais, v. 5, n. 3, 2019.

UNESCO. 2009 World Conference on Higher Education: The new dynamics of higher education and research for societal change and development. Final Report. Paris: UNESCO, 2009. Disponível em: 
PROCESSO DE ELABORAÇÃO NORMATIVA E POLÍTICAS PÚBLICAS: A VISÃO JURÍDICOINSTITUCIONAL DA POLÍTICA DE FORMAÇÃO DE PROFESSORES DA EDUCAÇÃO BÁSICA

https://unesdoc.unesco.org/ark:/48223/pf0000189242/PDF/ 189242eng.pdf.multi. Acesso em: 17 ago.2019

VARKEY FOUNDATION. Global Teacher Status -Index. University of Sussex, 2018. Disponível em: <https://www.varkeyfoundation.org/media/4867/gts-index13-11-2018.pdf>. Acesso em: 13 dez. 2018.

XIMENES, Salomão Barros. Direito à Qualidade na Educação Básica: teoria e crítica. São Paulo: Quartier Latin, 2014. 